\title{
Status Reinforcement in Emerging Economies: The Psychological Experience of Local Candidates Striving for Global Employment
}

\section{Citation}

Al Dabbagh, May, Hannah Riley Bowles, and Bobbi Thomason. "Status reinforcement in emerging economies: The psychological experience of local candidates striving for global employment." Organization Science 27, no. 6 (2016): 1453-1471.

\section{Permanent link}

http://nrs.harvard.edu/urn-3:HUL.InstRepos:38964228

\section{Terms of Use}

This article was downloaded from Harvard University's DASH repository, and is made available under the terms and conditions applicable to Open Access Policy Articles, as set forth at http:// nrs.harvard.edu/urn-3:HUL.InstRepos:dash.current.terms-of-use\#OAP

\section{Share Your Story}

The Harvard community has made this article openly available. Please share how this access benefits you. Submit a story. 
Status Reinforcement in Emerging Economies:

The Psychological Experience of Local Candidates Striving for Global Employment

*** in press at Organization Science ***

May Al Dabbagh

New York University Abu Dhabi

Hannah Riley Bowles

Harvard University

Bobbi Thomason

University of Pennsylvania

Author Note

This work was supported by grants from the Emirates Foundation, the Harvard Kennedy School Women and Public Policy Program, the Harvard Kennedy School Center for Public Leadership, and the Harvard University Middle East Initiative. We also thank the Gender and Public Policy Program at the Mohammed Bin Rashid School of Government for their logistical and administrative support of our data collection in the United Arab Emirates and Saudi Arabia. We gratefully acknowledge generous feedback on this manuscript from Linda Babcock, Frank Flynn, Michele Gelfand, Pamela Hinds and Ying Yi Hong. We owe special thanks for the research assistance of Maimoona Al-Bahandy, Amira Al-Hefaiti, Christine Assaad, Ghalia Gargani, Asmaa Ramadan, and Huda Sajwani.

The authors are listed in alphabetical order; all contributed equally to this paper. Correspondence concerning this article should be addressed to Bobbi Thomason, The Wharton School, University of Pennsylvania, 3016 Steinberg-Dietrich Hall, 3620 Locust Walk, Philadelphia, PA, 19104. 
Status Reinforcement in Emerging Economies:

The Psychological Experience of Local Candidates Striving for Global Employment

Abstract

In this paper, we explore the psychological experience of university-educated local workers from emerging economies striving to enter the global job market for managerial positions. Building on qualitative data from sub-Saharan Africa and the Arab Gulf, we conducted two experimental studies in the Arab Gulf to test whether local job candidates feel inhibited to self-advocate for higher compensation in global employment contexts and whether they believe that such negotiating behavior is less appropriate in global than in local work contexts. We theorize that shifting from local to global employment contexts, university-educated locals experience a decline in their status as workers because of a perceived lack of fit with the cosmopolitan "ideal worker." We find that the contrasting global and local labor-market experiences of local job candidates are moderated by gender because local men experience a greater shift in status between local and global employment contexts than do women. This research contributes to the study of status and gender effects on negotiation by illuminating differential constraints of status and gender on negotiating behavior. This research also has important practical implications for the integration and advancement of workers from emerging economies into global institutions and for our broader understanding of how intersecting status-linked social identities influence career negotiations.

Word Count: 206

Keywords: globalization, gender, intersectionality, negotiation, status, stereotypes, emerging markets 
Status Reinforcement in Emerging Economies:

The Psychological Experience of Local Candidates Striving for Global Employment

"When I go for an interview, the first impression they have is that I am a local. I am lazy . . This is the stereotype."

Local university graduate applying for work with multinational corporations

"I guess it falls under work ethic; it's different from what we expect . . It is really difficult for us to find locals fitting our expectations."

Hiring manager in a multinational corporation

In the global labor market, there is a differential valuation of the potential contributions of "locals" whose skills, knowledge, and experience set is associated with the national context and "cosmopolitans" who have accumulated international skills, knowledge, and experience (Haas, 2006). ${ }^{1}$

“Cosmopolitans" enjoy a higher status, as Kanter (1995) explains:

"Cosmopolitans are card-carrying members of the world class—often literally card carrying, with passports or air tickets serving to admit them ... Comfortable in many places and able to understand and bridge the differences among them, cosmopolitans possess portable skills and a broad outlook" (p. 22).

While some local expertise is valuable in international work (Haas, 2006), locals defy the prototype of the ideal global worker (Acker, 1990; Connell, 1998; Connell \& Messerschmidt, 2005; Freeman, 2001).

This contrast becomes particularly acute when locals are nationals of non-Western emerging economies, such as the Middle East, Africa, or Latin America (Gillespie, McBride \& Riddle, 2010; Rissing \& Castilla, 2014). "Global” business culture is associated with Western capitalist values and logics (e.g., being analytic, competitive, performance-driven) that stand in contrast to associations with traditional non-Western business cultures (e.g., relationship-oriented and historically determined business practices) (Erez \& Shokef, 2008; Fu \& Chiu, 2007; Hong, Wan, No, \& Chiu, 2007; Sanchez-Burks \& Lee, 2007). As illustrated by the opening quotes, there is a perceived "lack of fit" (Heilman, 1983) between the local and the ideal global candidate. 
Once hired, local employees tend to be compensated systematically less than their cosmopolitan (e.g., expatriate or "international") colleagues in multinational organizations. Even in economic development where local knowledge has distinctive value (Haas, 2006), professionals from wealthy economies are paid at "international rates" whereas professionals from emerging economies are paid at lower "local rates" (Carr, 2010; Leung, Zhu \& Ge, 2009). It is rational for compensation to be informed by cost-of-living differences, but some argue that documented pay gaps ranging from 4:1 to 9:1 controlling for in-country purchasing power are too extreme (Carr, 2010; Carr, MacLachlan \& Chipande, 1998). Carr (2010) explains:

"When dual salaries were first introduced, in the last century, they at least had a modicum of rationale. They were based on an assumption that local capacity was relatively low, lending a premium to expatriate skills. Today however, the landscape is considerably changed, and the policy much less defensible."

There is similar evidence of gross pay disparities between expatriate and local employees in international joint ventures and of how perceptions of unfair compensation systems contribute to demoralization of local employees (Choi \& Chen, 2007; Leung, Zhu, \& Ge, 2009). Pay inequities between cosmopolitans (i.e., expatriates or "internationals") and locals reinforce locals' lower status (MacLachlan, Carr \& McAuliffe, 2010; Ridgeway, 1998; Ridgeway, 2001).

Non-material inequalities between cosmopolitan and local workers have also been documented in a variety of locations and industries worldwide. Studying professional interactions in multinational employment settings, qualitative researchers have documented how cosmopolitans are also afforded greater deference than their local peers. For example, Metiu (2006) conducted an ethnographic study of a California-based U.S.-Indian software development team. She documented how the Americans distanced themselves from their "local" Indian colleagues by making claim to higher-status creative (vs. lowerstatus technical) work and by segregating both online communications and face-to-face social interactions. In another study of status hierarchies in global work, Neeley (2013) examined the transition to English as the lingua franca in a European multinational corporation. She illuminated how increasing 
deference to more fluent English speakers led to a decline in the professional status of less fluent English speakers. Leonardi \& Rodriguez-Lluesma (2014) studied engineering teams in a global corporation and documented how the perceived cross-national "pecking order . . of engineering centers" (p. 489) negatively influenced the quality of international collaboration. Explaining what he perceived as disrespectful treatment, a Mexican engineer lamented that his American and European colleagues "think we're not as good engineers as them and they think they're higher status" (p. 492). Deferential treatment of cosmopolitan employees reflects and reinforces the status hierarchy between "global" and "local" workers in multinational employment contexts (Ridgeway \& Erickson, 2000; Ridgeway, 2001).

In this research, we study the psychological experience of university-educated local workers from emerging economies striving to enter the global job market for managerial positions. We present data from qualitative interviews and pretest surveys to illuminate the job market context for locals pursuing global corporate employment, including evidence from Sub-Saharan Africa and the Arab Gulf. In two experimental studies conducted in the Arab Gulf, we test whether local job candidates feel inhibited to self-advocate for higher compensation in global employment contexts and whether they believe that such negotiating behavior is less appropriate in global than local employment contexts because it defies the normative expectations of low-status behavior. In conclusion, we discuss practical implications of behavioral norms that inhibit the agency of local employees in global institutions.

\section{Status, Gender, and Self-Advocacy in Global Employment}

We focus on negotiation because it is one of the fundamental social processes in organizational life (Barley, 1991; De Dreu \& Gelfand, 2007; Graham, 1995; Katz \& Kahn, 1966; Pfeffer, 1981). It is also a mechanism of career advancement that is not equally accessible to all employees (Bowles \& McGinn, 2008). Organizational researchers have long documented that status-linked social identities influence the outcomes of implicit negotiation processes that affect career advancement, such that employees belonging to higher-status social groups (e.g., men versus women, Whites versus Blacks) are more successful at attaining organizational resources and opportunities (Brass, 1985; Dreher \& Cox Jr, 2000; Dreher \& Cox, 1996; Miller, Lincoln, \& Olson, 1981). 
Recent research on gender in negotiation has provided greater depth of perspective into this phenomenon. U.S.-based field and laboratory studies have shown that women feel more reticent than men to negotiate for career rewards, such as higher compensation (Babcock, Gelfand, Small, \& Stayn, 2006; Babcock \& Laschever, 2003; Small, Gelfand, Babcock, \& Gettman, 2007) because self-advocating for higher pay violates feminine prescriptions of communality (i.e., warmth and concern for others) (Amanatullah \& Morris, 2010; Bowles et al., 2007; Bowles \& Babcock, 2013). There is some debate, however, about whether these documented gender effects are better explained by power and status differences between men and women or by gender per se (e.g., Amanatullah \& Tinsley, 2013; Magee, Galinsky, \& Gruenfeld, 2007).

While communality is a central prescription of the feminine gender role (Eagly, 1983), it also a broader prescriptive expectation of low-status actors. For instance, Conway, Pizzamiglio, \& Mount (1996) demonstrated experimentally that even interpreting fictional accounts (i.e., of the "Bwisi and Mwangai ... living in the Caroline Islands in the western Pacific ocean"), low-status groups were ascribed communal traits and high-status groups agentic ones. In their extensive review and categorization of stereotypes in the Stereotype Content Model, Fiske et al. (2002) explain that "paternalistic stereotypes" assign high communal warmth and low-competence to a wide range of low-status groups, including disadvantaged Blacks, elderly people, nonstandard speakers, and traditional women (p. 880). In experiments designed to establish status hierarchies, Ridgeway and colleagues documented a propensity for disadvantaged groups (e.g., the lower paid or those treated with disregard) to be viewed, and to also view themselves, as more communal (i.e., socially considerate) to compensate for a perceived lack of competence (Ridgeway, Boyle, Kuipers, \& Robinson, 1998; Ridgeway \& Erickson, 2000). Expectations of communal behavior make members of low-status groups more socially attractive and less threatening (Brown \& Levinson, 1987; Jackman, 1994), and low-status group members can enhance the perceived value of their contributions through expressions of concern for group welfare (Ridgeway, 1978).

Following the arguments that communality is not only a prescriptive stereotype for women but for low-status people more generally and that self-advocating for greater resources or rewards at work 
(e.g., higher compensation) violates expectations of communal behavior (Amanatullah \& Morris, 2010; Bowles et al., 2007), we propose that low-status men will also feel more inhibited than high-status men from negotiating for higher pay. However, in U.S. studies testing for power or status as a moderator of gender effects in negotiation, manipulations have only affected the behavior of women and not men. For instance, priming study participants with the psychological experience of high power (as compared to control or low power) enhanced women's, but not men's, propensity to negotiate, (Magee et al., 2007; Small et al., 2006). Amanatullah \& Tinsley (2013) found that participants evaluated assertive female negotiators less negatively when they held higher-status organizational positions (i.e., "Executive" as compared to "newly hired Junior Officer"), but title had no significant effect on the evaluation of assertive male negotiators. This pattern of results suggests that women's negotiating behavior is constrained by their social status relative to men, but it does not shed light on the question of whether men's negotiating behavior might also be constrained by diminished social standing.

We aim to build upon and extend this research by expanding the aperture of our investigative lens to encompass broader populations of men than are typically found in the privileged Western samples generally employed by negotiation researchers (Henrich, Heine, \& Norenzayan, 2010; cf., Ayres, 1995). Focusing on the employment markets for university-educated local job candidates offers a rich opportunity to examine effects of status and gender on career self-advocacy. Shifting from local to global employment contexts, university-educated locals experience a decline in status as workers. In the local employment context, they are among the most talented workers their national universities produce, whereas, in the global employment context, they tend to suffer a perceived lack of fit with the cosmopolitan “ideal worker” (Acker, 1990; Connell, 1998; Williams, 2000).

We theorize that the contrasting global and local labor-market experiences of local job candidates are moderated by gender because local men experience a greater shift in status between local and global employment contexts than do women. In the local employment context, men tend to hold higher status than women. In the global employment context, gender status hierarchies persist but there is also the hierarchy between cosmopolitan and local employees. Testing effects of gender as well as employment 
context on the evaluation of locals' negotiating behavior enables us to explore whether women's propensity to self-advocate is perceived differently than that of low-status men and specifically whether gender stereotypes as well as social status constrain women's negotiating ability.

This research contributes to the literature on global work a deeper understanding of the experience of university-educated local workers approaching global employment markets and gives insight into how local men's and women's expectations and experiences may differ. This research also contributes to the study of status and gender effects on negotiation by illuminating differential constraints of status and gender on negotiating behavior and the intersectional nature of gender identities in global work. This research has important practical implications for the integration and advancement of workers from emerging economies into global institutions and for our broader understanding of how status-linked social identities influence career negotiations.

\section{Hypotheses}

Research Context. We conducted our two main studies in the Arab Gulf, a rapidly globalizing emerging market known as the "beating heart of globalization in the Arab world" (Hudson, 2006, p. 148). The Arab Gulf is widely known to have a distinctive economic history stemming from the oil boom, but it shares much in common with other regions of the world experiencing rapid economic globalization. There are many parts of the world — from Brazil to South Africa to Thailand—where locals are striving to build their national economies and career prospects by joining the global job market.

To gain insight into the psychological experience of locals striving for global employment, we recruited our main study participants from "reform universities" in the Arab Gulf, specifically in Saudi Arabia (Study 1) and the United Arab Emirates (Study 2). To prepare young nationals for the global employment market, both Saudi Arabia and the UAE have created reform universities with Englishmandated instruction. The mission of reform universities is to prepare students for global employment (e.g., "committed to preparing highly qualified students to become leaders who are globally competitive, entrepreneurial and dedicated to the betterment of society" or "where students graduate with the skills they need to meet the challenges of today's international global environment"). Many faculty are foreign 
nationals from Western industrialized economies. The aim is for reform university students to graduate as global-local biculturals (Arnett, 2002)-immersed through their university experience in the language (i.e., English) and "workways" (i.e., the "culture's signature pattern of workplace beliefs, mental models, and practices that embody a society's ideas about what is true, good, and efficient within the domain of work," Sanchez-Burks \& Lee, 2007, p. 346) of "global” business.

These reform university students are the most competitive local university graduates for global employment. They have invested in an education designed to enhance their cosmopolitan status. This is important to highlight because it makes our tests both more conservative and realistic because they are the most viable candidates for global employment among local university graduates. We would expect our predicted status effects to be stronger if tested among university students who had not benefitted from years of English-immersion and Western business training.

Hypothesized Effects of Status and Gender on Local's Self-Advocacy. Building upon our discussion above about gender, status, and self-advocacy in global employment, we now explain our predictions within the research context. Our leading prediction is that local university graduates will be more inclined to self-advocate for higher pay in a local than in a global employment context because local university graduates have higher status in local than in global employment contexts. We based this prediction on research already discussed, indicating that self-advocating for greater resources or rewards at work (e.g., higher compensation) violates the normative expectations of low-status behavior.

Hypothesis 1: Local job candidates will be more inclined to self-advocate for higher compensation in a local than global employment context.

However, we predict that gender will moderate this main effect of employment context on the propensity to negotiate for higher pay because employment context has a greater effect on local men's social status at work than on local women's.

In the countries in which we conducted our research—Saudi Arabia and the United Arab Emirates (UAE), male nationals retain overwhelming control of economic resources and authority positions in government and the domestic private sector (Hausmann, Tyson, \& Zahidi, 2015). In spite of 
university graduation rates for women that surpass men's, women occupy only a fraction of the workforce. For instance, labor statistics indicate that women hold less than a quarter of professional and technical roles (e.g., 24 percent in Saudi Arabia, 22 percent in the UAE) (Greig, Hausman \& Zahidi, 2015). In this context, men are often the presumed breadwinners for the family, and women are expected to assume family care-giving roles (AlMunajjed, 1997; International Labor Organization, 2012; Metle, 2002; The World Bank, 2013). Those women who are employed work mostly in the public sector or in lower-level positions in the private sector (Booz \& Co, 2011). In sum, because men have higher status than women in the local employment context, we hypothesize that men will feel at greater liberty than women to negotiate for higher pay.

Hypothesis 2: In the local employment context, local men will be more inclined than local women to self-advocate for higher compensation.

In the global employment context, local men no longer belong to the ruling class and, as discussed above, suffer a lack of fit with the cosmopolitan ideal worker (Connell, 1998; Connell \& Messerschmidt, 2005). While local men experience a decline in status shifting from the local to the global employment context, local women tend to be ascribed lower status than the dominant class of men in both the local employment context and in the Western industrialized employment contexts of global corporations (Ridgeway, 2011). There is some evidence of liberal Western values bolstering the workplace status of Arab women in the global as compared to local work context (Metcalfe, 2006, 2007) and of global employers expressing hiring preferences for local women over local men in emerging economies (Ahmed, 2004; Fernandez, 2005; Jensen, 2012; Ng \& Mitter, 2005). These dynamics put local women in a more competitive position relative to local men in the global as compared to the local employment context, but local women never escape the global gender status hierarchy (Ridgeway, 2011). In sum, we predict that men will feel at greater liberty to negotiate for higher pay in the local than in the global employment context and that gender will moderate the main effect of employment context on the propensity to negotiate for higher pay predicted in Hypothesis 1.

Hypothesis 3: Local male job candidates will be more inclined to self-advocate for higher 
compensation in the local than in the global employment context.

Hypothesis 4: Gender will moderate the effect of global (vs. local) employment context on local job candidates' propensity to self-advocate for higher compensation, such that the effect of employment context (Hypothesis 1) will be greater for local men than for local women.

Drawing on research on gender and status in self-advocacy, we theorized that low-status actors feel inhibited from negotiating for higher pay because it violates the normative expectations of low-status behavior, specifically, communality. Therefore, we wanted to test how locals would perceive a male or female local who self-advocated for higher pay. Would they perceive a local negotiating for higher pay as insufficiently communal and, therefore, as a less desirable employee? If so, that could help to explain their reticence to negotiate in contexts in which they hold lower status.

One method of assessing how negotiating for higher pay is perceived is to compare how evaluators rate an employee who negotiates to how evaluators rate the same employee letting an opportunity to negotiate pass (e.g., Bowles et al., 2007; Bowles \& Babcock, 2013; Duguid \& ThomasHunt, 2015). One measure of the perceived desirability of an employee is evaluators' expressed willingness to work with them (e.g., Bowles et al., 2007; Duguid \& Thomas-Hunt, 2015). As an indicator of the perceived inappropriateness of low-status actors self-advocating for higher compensation, we predicted that local evaluators would express less willingness to work with local employees who negotiated for higher pay in a global employment context.

Hypothesis 5: In the global employment context, local evaluators will express less willingness to work with local employees who negotiate for higher pay as compared to local employees who let the opportunity to negotiate pass.

While it might be inappropriate for both male and female locals to negotiate for higher pay in a global employment context, we predicted that gender would moderate evaluations of local employees who negotiated for higher pay in a local employment context. In the local employment context where local men have higher status than local women, we predicted that local evaluators would perceive local men negotiating for higher pay as more socially appropriate than local women doing the same. 
Hypothesis 6: In the local employment context, gender will moderate the effect of self-advocating for higher compensation on locals' willingness to work with a local employee, such that the negative effect of negotiating (as compared to not negotiating) on the willingness to work with a local employee will be greater if the negotiator is a woman than if the negotiator is a man.

Building from Hypotheses 5 and 6, we predict that employment context will moderate locals' evaluations of male locals who negotiate for higher pay. Because men have lower status in the global than in the local employment context, we predict a stronger negative effect of negotiating on locals' willingness to work with a male local in the global than in the local employment context.

Hypothesis 7: Employment context will moderate locals' willingness to work with a local male employee who self-advocates for higher compensation (as compared to letting the opportunity to negotiate pass), such that the negative effect of negotiating for higher pay on the willingness to work with a male local will be greater in the global than in the local employment context. We theorized that locals would perceive a local who negotiated for higher pay as a less desirable employee because self-advocating for higher compensation would violate normative expectations that low-status actors behave communally. Communal behavior focuses on relationships with others ahead of the self. Therefore, we predicted that the effects proposed in Hypotheses 5-7 would be explained by a perceived lack of communality on the part of local employees who negotiate for higher pay (as compared to those who let the opportunity to negotiate pass).

Figure 1 illustrates this hypothesized mediation effect when the local employee is male. Male locals have relatively lower status in the global as compared to local employment context and are, therefore, likely to face stronger expectations that they behave in a communal manner in the global than in the local employment context. We predicted that employment context would moderate the effect of negotiating for higher pay on how communal local men appeared, such that the effect of negotiating (as opposed to not negotiating) would have a stronger negative effect on the perceived communality of local men in the global employment context (where they have low status) than in the local employment context (where they have high status). As illustrated in Figure 1, we hypothesized that these heightened 
expectations of communal behavior on the part of local men in the global (as compared to local) employment context would explain the moderating effect of employment context on locals' willingness to work with a local male employee who negotiates for higher pay (as compared to one who lets the negotiation opportunity pass).

Hypothesis 8: Perceived communality will explain the moderating effect of employment context on the willingness to work with a local male employee who self-advocates for higher pay (as compared to one who lets the opportunity to negotiate pass) (Hypothesis 7).

\section{[INSERT FIGURE 1 APPROXIMATELY HERE]}

As has been documented in U.S. studies, we predicted that local evaluators would express less willingness to work with local women who negotiate for higher pay (as compared to letting the opportunity to negotiate pass) because negotiating would make local women appear less communal (Bowles et al., 2007; Bowles \& Babcock, 2013; Duguid \& Thomas-Hunt, 2015). To differentiate effects of gender from status effects more broadly, we tested whether self-advocating for higher pay would also make local women appear to have violated other behavioral expectations specific to women in the Arab Gulf related to "modesty" and the rejection of "materialism." Modesty has been identified as the primary prescriptive stereotype for Arab women (Abu-Lughod, 1998; Haddad \& Esposito, 1998), and it carries over into professional work settings_-particularly in gender-mixed work environments (Metcalfe, 2006). In Arab cultures, materialism is associated with excessive or overzealous pursuit of monetary rewards and is generally perceived as a negative trait in both men and women. We theorized that a local woman negotiating for higher pay would trigger perceptions of materialism because the deeply institutionalized male breadwinner model associates women's earnings with personal consumption (AlMunajjed, 1997; Metcalfe, 2007; Metle, 2002; Saliba, Allen, \& Howard, 2002). In sum, we predict that declines in the willingness to work with a local woman because she negotiated would be explained by perceptions that she is insufficiently modest and excessively materialistic as well as insufficiently communal.

Hypothesis 9: Locals will express less willingness to work with a local female employee who self-advocates for higher pay (as compared to one who lets the opportunity to negotiate pass) 
because negotiating will make the woman appear insufficiently communal and modest and excessively materialistic.

\section{STUDIES}

As described in more detail in the following section, we conducted four preliminary studies of the research context to illuminate the experience of being a local university graduate striving for global employment. Subsequently, in our two main studies, we tested our hypotheses on the effects of gender and global/local employment context on locals' propensity to self-advocate for higher compensation (Study 1) and on evaluations of locals who negotiate for higher pay (Study 2).

\section{Exploratory Studies of Research Context}

\section{Interview Study}

We set the stage by reporting on interviews with hiring managers from multinational enterprises in two emerging markets: the Arab Gulf ${ }^{2}$ and Sub-Saharan Africa ${ }^{3}$, which is another rapidly globalizing region (McMillan, Rodrik \& Verduzco-Gallo, 2014). We focused our interviews on the United Arab Emirates and South Africa, which, since the lifting of Apartheid, has been the spear tip of Sub-Saharan Africa's entry into the global economy. As in the Arab Gulf, English is the lingua franca of international business in Sub-Saharan African amidst a plethora of other local languages (Statistics South Africa, 2011).

Methods. We investigated perceptions of "ideal" and "local" workers in the global job markets of these emerging economies through interviews with 15 hiring managers and recruiters in the United Arab Emirates and South Africa who were identified through professional referrals. None were knowledgeable about our research. We informed them that we were interested in their experiences hiring talent for global organizations. All interviews were conducted in-person at the interviewee's workplace and lasted 40-70 minutes with the exception of two interviews conducted via videoconference on Skype.

All interviews followed the same semi-structured protocol, which opened by asking the managers to describe the "ideal employee" (e.g., qualifications, attributes). This question was followed by questions about recruitment practices and leadership development initiatives. The only reference that interviewers 
made to locals was to ask at the end of our protocol, "What is your organization doing in terms of local leadership development?"

Contrasting Descriptions of Ideal and Local Workers. The most consistent theme in response to questions about the ideal candidate was a desire for cosmopolitan workers with international, particularly Western, work experience. Table 1 displays representative quotes about the competences of ideal global workers and the lack of fit of local workers with these ideals. As one interviewee from a multinational technology company in the UAE explained:

"The individual must have the skill set that matches the product or services needed ... But more importantly, the person should be able to work with teams in different countries and time zones. They should have a communication style that is effective with different cultures and audiences. They need to be aware of how different cultures work . . . This global perspective is very important."

There were also repeated references to speaking English as a global competence and to international work experience in English-speaking markets. One hiring manager in the UAE posited that, "[English] language competency is correlated with skill sets like financial knowledge.”

Without our introducing the term, 12 of the 15 the interviewees referred to "locals" or "local candidates" as lacking not only in international business skills, knowledge, and experience, but also in work ethic. There were numerous blanket references to local candidates as inadequate. A hiring manager in the UAE said, "We recruit people who are educated abroad or through bank referrals, because ... the local candidates are not really qualified." Another hiring manager in the UAE explained, "Recruiting locally is a struggle. I mean we struggle with finding local talent. The results are mixed for local hiring."

Male Embodiment of the Local Stereotype. Consistent with recent research showing that men tend to be the carriers of national stereotypes (Cuddy, Wolf, Glick, Crotty, Chong \& Norton, 2015), our interviewees tended to depict the archetype of the "local worker" as a man. Local job candidates were often referred to as "local men" or "local guys." For instance, one interviewee reported that expatriates were "prepared to work much harder than your local guy." Another discussed the impossibility of hiring 
"guys that had never been out of their country." Interviewees recounted examples of local men who were unqualified, not working hard enough, promoted too quickly, or too quick to take a new position. Only once was a woman described as not fitting the organizational culture. Describing relative perceptions of local women as compared to local men, one interviewee commented, "It's not only a belief that all people are equal, it's that, 'Geez, these women are good workers!' You know, like they're genuinely good managers. They're good organizers. They understand our brand sensibility." Nonetheless, anytime interviewees described actual or hypothetical executive positions they referred to a man or used male pronouns.

Discussion. In sum, data from interviews with hiring managers in two emerging markets were consonant with our theorization of locals as low-status job candidates in the global market. As illustrated in Table 1, there was remarkable consistency across the two regions in hiring managers' accounts of the attributes of ideal global workers and in their commentary on the "lack of fit" (Heilman, 1983) of local candidates with that ideal. English language competence was a prime signifier of global competence. Local workers, generally characterized as men, were consistently described as lacking in the desired cosmopolitan competences and self-presentation, particularly language skills.

\section{Pretest Survey}

The contrasting images of the ideal global worker and local job candidates in our interviews with global hiring managers align with the findings of survey research on negative perceptions of local workers held by employers in the Arab Gulf (Al-Waqfi \& Forstenlechner, 2010, Forstenlechner, Madi, Selim, \& Rutledge, 2012; Mellahi, 2007; Rees, Mamman and Bin Braik, 2007). Building on these qualitative data, we conducted a survey to test for awareness of these stereotypes of local job candidates among university-educated citizens of the Arab Gulf and to test whether the gender of the local candidate moderated perceptions of the degree of negative stereotyping (e.g., harsher evaluations of local men than of local women). We had observed press coverage in the Gulf on the negative stereotyping of local job candidates (e.g., "Stereotypes Can Stymie the UAE's Development," Abdulla, 2010) and on the reverse gender gap in academic achievement (e.g., "UAE women reverse gender gap in education, outperform 
their male counterparts," Thottathil, 2014), which is part of the narrative behind growing preferences for hiring local women. Interviews with private sector employers revealed that they perceived local women as having better English language competence and higher educational attainment than local men, while at the same time being more willing than local men to accept junior positions for low pay (Rutledge et al., 2011).

Method. A market-research company recruited 105 university-educated Emiratis with work experience to complete an online survey in Arabic on perceptions of Emirati university graduates on the job market (38 men, 67 women; $M$ work experience $=7$ years). Participants were randomly assigned to one of four conditions in a 2 (Local Graduate Gender: Male/Female) $\times 2$ (Global/Local Employer) between-subjects design. We manipulated employment context by referring to prospective employers as local or global companies and by adding corresponding national or international flags in the survey header. We manipulated the gender of the local university graduate with gendered nouns, adjectives, and pronouns. The survey asked participants" opinions "about the views that employers in [global/local] companies typically hold about [male/female] Emirati university graduates seeking work in [global/local] companies.” Participants rated perceptions on seven criteria: ambitious, capable, competent, knowledgeable, reliable, respected, skillful. We averaged responses to these items to create a perceived competence scale $(\alpha=.94)$.

Findings. The results supported our prediction that locals would perceive global employers to have a dimmer view of their male university graduates than local employers would. ANOVA revealed an interaction of Gender $\times$ Global/Local, $F(1,101)=6.90, p=.01, \eta^{2}=.06$. No other effects were significant, $F \mathrm{~s}<2.08, p \mathrm{~s}>.15$. As illustrated in Figure 2, participants rated male graduates' perceived competence as lower with global than local employers $($ global mean $=2.88, \mathrm{SD}=1.04$; local mean $=$ $3.67, \mathrm{SD}=1.07 ; t[49]=2.67, p=.01, d=.76)$, but not female graduates' (global mean $=3.60, \mathrm{SD}=0.90$; local mean $=3.37, \mathrm{SD}=0.91 ; t[52]=0.91, p=.37, d=.25)$. In the global employment condition, perceived evaluations of male graduates were lower than those of female graduates $(t[43]=2.47, p=.02$, $d=.75)$, but not in the local employment condition $(t[58]=1.17, p=.25, d=.31)$. 
Discussion. The results of this pretest survey affirmed that educated citizens of the Arab Gulf are aware that local university graduates and male graduates, in particular, are more negatively stereotyped as job candidates in the global than in the local employment market. To further enrich our understanding of the psychological experience of the global employment market for local university graduates, we conducted focus groups with university students about their job market experiences. We focused on students at reform universities because, as explained above, these are institutions dedicated to preparing young Gulf nationals for the global employment market.

\section{Focus Groups Study}

The primary purpose of the focus groups was to devise experimental materials that would resonate with and feel relevant to the student participants, specifically our manipulation of global and local employment contexts and the negotiation scenario. We held four focus groups in Saudi Arabia and the UAE in the male and female sections of reform universities.

Method. A Western-educated, bilingual female Gulf national facilitated each of the conversations. Each focus group was held with 8-12 English-Arabic bilingual undergraduate students who had previously experienced an interview for a work placement or internship. The students ranged in age from 19 to 21 (mean = 20 years). Focus groups were 1-2 hours long and were recorded, transcribed, and content analyzed. Transcripts were 40-60 pages each and included rich narratives in English and Arabic.

Recognition of the Competitive Demands of the Global Employment Market. It was clear from the focus group conversations that the students were conscious of the competitive demands of the global employment market in the Gulf. For instance, one student explained:

"Every person ... has to have certain qualifications, has to take courses, certain language certificates ... The [globalizing economic] development is very intense, and from it we got a diversity of jobs and there is more competition and more diversity in jobs. Everyone wants to be the best ... and every company wants to be [the best]."

Another student added, "When the development happened ... the jobs became more plenty and everyone markets himself. Like what [other participant] said, you are in the business of marketing yourself." 
Identification of English with Global Employment. As expected for reform university students, focus group participants were comfortable and competent speaking English and Arabic. One explained:

"[They] always say to us 'express yourself' and university life forces the student to be expressive in English. That is why after graduating I feel that it is easy for me to express myself in English.

Because the university made me used to it."

Consonant with the views of global hiring managers (described above), the students explained their preparations for the global employment market as inextricably linked to speaking English. For instance, one participant explained:

"Actually all the terminology ... here as business students [is] in English. We were speaking once ... and I forgot what competition means in Arabic. It's منافسة [munafasa] I know now, but I completely forgot it. I never said منافسة [munafasa for competition] here at the university."

As illustrated in the following quote, students described self-presentation in English as a status marker in global employment: "If a client approaches me ... [and] I speak to him in English in a nice manner and impress him, he will keep coming back to me ... That will surely . . give me status at my work."

Stereotypes of Local Job Candidates. The students expressed awareness of negative stereotyping of local university graduates. The opening quote in this paper about the "lazy local" stereotype came from the focus group conversations. One student raised the issue of differential perceptions of male and female graduates, sharing a story about an HR manager who told him that he preferred to "employ females because they are punctual and the work they do is better than the males."

Discussion. As in our interviews with global hiring managers (see Table 1), the reform university students made repeated references to English as the language of global business. They explained further how they have learned to self-present in business English to signal their global competence. Nonetheless they were acutely aware of ways in which they are negatively stereotyped. The female students also felt subject to negative stereotyping as locals, but there was some discussion of global employers preferring to hire female rather than male locals.

Pretest Survey of Negotiation Scenario 
We conducted a pretest of the negotiation scenario in the local employment context. The negotiation scenario was adapted from studies run in the United States (Bowles, et al., 2007). Interviews with individuals knowledgeable about the job market experiences of local university graduates suggested that compensation negotiations would be more appropriate if one had an outside offer, so we tested that impression with a sample of university graduates with recent job market experience. Twenty-three graduate students from the Arab Gulf enrolled in an Emirati professional school ( $M$ age $=33.35$ years) responded to an online survey. We asked respondents to read our negotiation scenario and rate how information on an outside offer would influence their impressions of the employee negotiating for higher compensation and their willingness to work with or hire them (worse-to-better 7-point scales). The outside offer significantly improved participants' impression of the employee (mean difference from midpoint $=0.78, t[22]=3.12, p<.01)$, but had no effect on their willingness to work with or hire the employee (mean difference from mid-point $<0.31, p \mathrm{~s}>.29$ ). From the interviews and survey results, we concluded that information on an outside offer would enhance the ecological validity of our study. In studies of job negotiations, information about outside offers has been shown to increase negotiators' sense of power and propensity to initiate negotiations (Magee et al., 2007) and the perceived legitimacy of negotiating for higher compensation (Bowles \& Babcock, 2013). We concluded that this information would only make our tests for behavioral constraints on negotiation more conservative.

\section{Study 1}

In Study 1, male and female reform university students wrote about how they would handle an opportunity to negotiate in either a local or global employment context. We employed a 2 (Participant Gender: Male/Female $) \times 2($ Employment Context: Local/Global $)$ study design. We tested our hypotheses that local job candidates would be more inclined to self-advocate for higher pay in a local than global employment context (H1), that local men would be more inclined to self-advocate for higher compensation than women in a local employment context $(\mathrm{H} 2)$, and that gender would moderate the main effect of employment context on the propensity to negotiate for higher pay such that the effect of employment context would be greater for men than for women (H3). 
Participants. Participants were 157 Saudi nationals who were full-time students in the men's and women's colleges of two different Saudi Arabian reform universities (79 men, 78 women; $M$ age $=21.79$ years). There were no statistically significant effects for university, so we pooled the data. We gained the permission of university administrators and classroom faculty to recruit students to complete an "Interview Situation Survey" during class time.

Materials. As explained above, we developed the materials for Studies 1 and 2 starting with American job negotiation scenarios (Bowles \& Babcock, 2013; Bowles et al., 2007) that we adapted to fit the global and local employment contexts of the Arab Gulf. Participants read a two-part scenario. Part 1 involved imagining they were interviewing for a desirable position at a company in Saudi Arabia. Part 2 was about receiving an offer from The Company and entering an interview about a management placement. The job placement interview created an opportunity to negotiate for higher compensation to match a competing offer. The English-language description of the negotiation opportunity was as follows:

The position The Company is offering is one that you would like to take, but the compensation offer is lower than your next best offer from a less prestigious firm. You would like to accept the offer from The Company, but you are hoping that they will match the salary and bonus offer you received from the less prestigious firm. You have decided to ask the head of the department into which you are being hired — this is the same person with whom you interviewed - if The Company would consider raising your compensation to match your other offer.

\section{Manipulation of Employment Context}

Because our participants were bilingual in Arabic and English and they-as well as the global hiring managers - described self-expression in English as a signal of global employment competence, we chose to manipulate employment context using a language prime: Arabic materials for the local employment context and English materials for the global. This choice has practical as well as theoretical merits. From a practical perspective, it was appropriate for interview scripts and scenarios to be presented in the language of the employment context. As illustrated by the quote above in which the student recalled 
forgetting the word for "competition" in Arabic, thinking and reading dialogue in Arabic would be incongruent with a global employment context. Similarly, it would be inauthentic to carry on a local business dialogue in English.

From a theoretical perspective, there is a broad body of studies employing language primes to evoke mental representations that contain culture-congruent content, procedures, and goals (e.g., Morris, Mok \& Mor, 2011; Oyserman, 2011; Tong, Hong, Lee \& Chiu, 1999; Ross, Xun \& Wilson, 2002; Zhang, Morris, Cheng \& Yap, 2013). Language has also been used to activate contrasting identity-linked selfconcepts in bilingual biculturals. For instance, in multiple studies, researchers have activated a more individualistic self-concept in Chinese biculturals when they completed materials in English as compared to when they wrote in Chinese example (e.g., Lee, Oyserman, and Bond, 2010; Ross, Xun, \& Wilson, 2002). Our aim through the language primes was to activate participants' sense of identity as a local job candidate in global and local employment contexts.

In Studies 1 and 2, we translated the materials using a combination of the committee approach and translation-back-translation (van de Vijver, 2001). Three bilingual committee members with expertise in psychology, linguistics, and Arab Gulf culture translated the materials from English into Arabic. A fourth independent translator converted the Arabic draft back into English as a final consistency check between the English and Arabic versions. The committee resolved minor discrepancies between the original English draft and the back-translated version.

Procedure. The experimenter asked participants to complete a pen-and-paper survey about an employment scenario and randomly assigned participants to the global or local employment condition. All experimenters administering the surveys were Saudi nationals. In the male colleges, the experimenters were male and, in the female colleges, the experimenters were female. In the global (local) employment condition, the survey materials were in English (Arabic) and described the employer as a prominent multinational (national) corporation. Participants responded to the survey in the language in which it was written. After reading each part of the scenario (described above under Materials) participants recorded how they would feel, what they would think, and what they imagined they would say in this situation. 
Exiting the survey, participants responded to two language-proficiency questions about comfort speaking in Arabic and in English (5-point scales).

Manipulation checks. After the reading the first part of the employment scenario, participants responded to three sets of measures to test whether the language manipulation activated the anticipated contextual and identity-linked associations with the global and local employment contexts. As a test of activation of contextual work norms, we created a "wasta" scale averaging four items related to the local practice of relying on social connections to attain resources and opportunities (7-point scale, example: "I would need the recommendation of a wasta in this situation;” $\alpha=.88$ ). (See Appendix for wasta items.) The Arabic term "wasta" is similar "guanxi" in Chinese. We expected the students to associate wasta more strongly with the local (Arabic) than global (English) employment context.

To test for the activation of identity-linked associations with local and global employment markets, we used two sets of measures. We used a single-item measure of self-identification as "globalized" (5-point scale: "I consider myself a globalized Saudi ..."), which we expected to be lower in the local than global employment context. We also created two four-item scales of independent selfconstrual (7-point scale, example: "I am unique, separate from others;" $\alpha=.75)$ and interdependent selfconstrual (7-point scale, example: "I think of myself as connected to the students in my university;" $\alpha=$ .82) (adapted from Harb \& Smith, 2008, a measure validated in the Arab world). We anticipated that priming a local employment context would activate a more characteristically Middle Eastern selfconstrual which tends to be less independent and more interdependent than a typical Western selfconstrual (Buda \& Elsayed-Elkhoul, 1988; Harb \& Smith, 2008; Markus \& Kitayama, 1991).

Dependent measure. To discern the participants' propensity to negotiate, two bilingual research assistants who were blind to the hypotheses coded the participants' responses to Part 2 of the survey scenario. As described above, Part 2 of the survey presented an opportunity to negotiate in a job placement interview. We asked participants to: "Describe your feelings and thoughts as you take your seat and are about to ask for higher compensation.” This open-ended format enabled the participants to express their thoughts and emotions in their own words. Writing as well as reading also has been found to 
reinforce the strength of a language prime (Kemmelmeier \& Cheng, 2004). Blinded to the hypotheses, research assistants coded participants' responses in terms of their propensity to negotiate on a 3-point scale: 0 = weak (e.g., "I will not ask for higher compensation ... " or "I would be extremely nervous \& worried"), 1 = moderate (e.g., "I would feel a little bit hesitant, but put on a strong and confident face . . . " or "I would try to reinforce my confidence in myself and remind myself . . . it's the professional thing to do"), or 2 = strong (e.g., "I will feel excited because I already got the job and ... I've got nothing to lose" or "I feel confident about my ability \& that I deserve it"). There was high agreement between coders on what language indicated a weak, moderate, or strong propensity to negotiate (Inter-rater reliability $=.89$ ).

\section{Results and Discussion}

Language proficiency. There were no gender differences in self-reported language proficiency, $t \mathrm{~S}(155)<1.36, p \mathrm{~s}>.17 ;$ Arabic mean $=4.39, \mathrm{SD}=.83 ;$ English mean $=3.97, \mathrm{SD}=.89$.

Activation of global/local employment context. The results of our manipulation checks were consistent with the successful activation of contextual and identity-linked associations with the local and global employment markets in the respective conditions. Participants in the local (as compared to global) condition agreed more strongly with the need for wasta (local mean $=3.90, \mathrm{SD}=1.73$; global mean $=$ $3.32, \mathrm{SD}=1.86 ; t(155)=2.00, p<.05, d=.32)$, self-identified as significantly less globalized (local mean $=3.70, \mathrm{SD}=1.23 ;$ global mean $=4.33, \mathrm{SD}=.84 ; t(154)=3.56, p<.001, d=.57)$, and construed themselves as less independent (local mean $=5.53, \mathrm{SD}=1.51$; global mean $=6.11, \mathrm{SD}=.97 ; t(155)=$ $2.67, p<.008, d=.43$ ) and more interdependent (local mean $=4.44, \mathrm{SD}=1.29 ;$ global mean $=3.94, \mathrm{SD}$ $=1.22 ; t(155)=2.44, p=.02, d=.39)$. Gender did not moderate these effects, $F \mathrm{~s}(1,153)<1.32, p>.25$

Dependent measure: Propensity to negotiate. The three-level coding scale of the propensity to negotiate was not normally distributed (Shapiro-Wilk W $=0.78, p<.001$ ), so we used Ordered Logistic regression to test effects of employment context and gender on the propensity to self-advocate for higher compensation. We created a variable for employment context that was equal to 1 if local and 0 if global. We created a variable for participant gender that was equal 1 if the participant was male and equal to 0 if the participant was female. Table 2 displays the results of ordered logistic regression analyses testing the 
effect of employment context and participant gender on the propensity to self-advocate for higher pay.

As predicted in Hypothesis 1, the simple effect of local (as compared to global) employment context on the propensity to self-advocate for higher compensation was positive and statistically significant $(\log$ odds $b=1.59, p<.001)$. The odds of a one step increase in the propensity to negotiate (e.g., from weak to moderate or moderate to strong) were 4.9 times greater in the local than global employment context. However, as predicted, the effect of employment context was moderated by participant gender (Local $\times$ Male $\mathrm{b}=1.49, p=.03)$. Figure 3 presents a graphic illustration of this interaction in terms of log odds with female in global employment as the base case.

To test Hypothesis 2 that local men would be more inclined than local women to self-advocate for higher pay in the local employment context, we conducted Wilcoxon-Mann-Whitney tests of the effects of gender on the propensity to negotiate separately in the local and global employment contexts. As predicted, local men were significantly more inclined than local women to self-advocate for higher pay in the local employment condition, $\mathrm{z}=-2.50, p=.01$. There was no significant effect of gender on the propensity to negotiate in the global employment condition, $\mathrm{z}=0.80, p=.42$.

To test Hypothesis 3 that local men would be more inclined to self-advocate for higher pay in the local than in the global employment context, we conducted Wilcoxon-Mann-Whitney tests of the effects of employment context on the propensity to negotiate separately for male and female participants. As predicted, local men were significantly more inclined to self-advocate for higher pay in the local than global employment condition, $\mathrm{z}=-5.30, p<.001$. The effect of employment context on female participants' propensity to negotiate for higher pay was not significant, $\mathrm{z}=-1.56, p=.12$.

In sum, the results of Study 1 support Hypothesis 4 that gender moderates the effect of employment context on locals' propensity to self-advocate for higher compensation, such that the effect of employment context is greater for men than women. These results support our theorization that local men experience a greater shift in status than do local women moving from the local to the global employment context and that lower social status inhibits men's self-advocacy as well as women's. A possible alternative explanation for these results is that the men simply felt less confident negotiating in 
English than in Arabic. However, there were no gender differences in self-reported comfort speaking in English and Arabic. Language competence might explain the main effect of employment context on the propensity to negotiate (Hypothesis 1), but it could not explain the predicted and observed interaction effect of employment context and gender. In Study 2 we shed more light on this phenomenon by investigating how local university graduates perceive local men and women who negotiate for higher pay in local and global employment contexts. We test whether locals perceive a local who self-advocates for higher pay as a less desirable employee and whether this effect is explained by violations of normative expectations for low-status actors and for women specifically.

\section{Study 2}

We reversed the perspective on the negotiation scenario employed in Study 1 so that reform university students were now evaluating the behavior of a male or female local university graduate who negotiated or not for higher pay in the context of a job placement interview. Study 2 was a 2 (Local Employee Gender: Male/Female) × $2($ Employment Context: Global/Local $) \times 2($ Negotiate: Yes/No) between-subjects design. We designed the experiment so that we could test whether global/local employment context and employee gender moderated differences in evaluations of a local employee when they negotiated as compared to when they did not negotiate. If we only tested for main effects in perceptions of employees who negotiated, we would not be able to tell what effect the act of negotiating had on evaluations of the employee. For example, negative evaluations of negotiators in the global as compared to local employment context could simply be a main effect for employment context (e.g., harsher evaluations of locals in multinational than national companies) and have nothing to do with the act of negotiating. We aimed to test the impression created by self-advocating for higher pay.

This difference-in-difference analytic strategy (viz., testing differences between evaluations in the negotiation and no-negotiation conditions across the employee gender and employment-context conditions) is also important to avoid the problem of "shifting standards" in gender research (Biernat, 2003; Biernat, Manis, \& Nelson, 1991). Biernat and colleagues have shown that, when evaluators make subjective assessments of men and women, they are likely to mentally compare male targets to other men 
and female targets to other women. Even if evaluators are prone to think that men make better managers, they might rate a female candidate more highly than a male candidate because the female candidate is more exceptional "for a woman" (Biernat et al., 1991). This effect of shifting standards could be especially strong in the Arab Gulf because it is more exceptional for women to be candidates for management positions in the private sector than for men. Therefore, main-effect gender differences are less meaningful than the difference in difference across conditions.

\section{Method}

Participants. Participants were 393 Emirati nationals who were full-time students from three different national reform universities (125 male, 268 female; $M$ age $=21.05$ ). There were no statistically significant effects for university, so we pooled the data. With the permission of university administrators and classroom faculty, we recruited students to complete a "Job Interview Survey" during class time.

Procedure. Participants completed a pen-and-paper survey in which they read an interview transcript, answered questions about their impression of the interviewee, and completed an exit survey with manipulation checks. As in Study 1, the entire survey was written either in Arabic or English. The experimenters randomly assigned participants to complete one of the eight versions of the survey. The experimenters administering the surveys were female nationals of the Arab Gulf.

Materials. The interview situation and evaluation survey were written to be a mirror image of materials used in Study 1. Instead of putting themselves in the shoes of the job candidate, participants were asked to adopt the perspective of a senior manager evaluating an employee in a placement interview for a first management position in the company. The manipulation of employment context was the same as in Study 1 with students reading and completing the survey in English in the global condition and in Arabic in the local condition.

The employee they evaluated was a national university graduate with a traditional Emirati name. We manipulated employee gender using stereotypically masculine or feminine Emirati names (Hamad/Hamda) and gendered language (e.g., "he," "she") to describe the employee. We chose names that were not affiliated with a particular emirate, tribe, or social class. 
In the negotiation script, the employee responded to two questions about work experience and management training. The interviewer then asked, "Do you have any questions about your compensation and benefits package?" In the no-negotiate condition, the employee let this opportunity to negotiate pass. In the negotiate condition, the employee responded by negotiating for higher pay:

I do have some questions with regard to the salary and benefits package, though. I was approached by another company last week and they made me an offer for a management position. They are willing to pay me a higher salary than I would make here, plus a bonus. It wasn't clear to me whether this salary offer represents the top of the pay range. I understand that there's a range in terms of how much managers are paid in their first placement. I would like to be paid toward the top of that range. I would also like to be eligible for an end-of-year bonus.

Measures. Participants rated their agreement on 7-point scales with randomly ordered statements about the impression created by the employee in the interview transcript. (See Appendix for all items included in these impression measures.) These items comprised our mediator variables. Five statements related to how communal the employee seemed (e.g., "puts people first") ( $\alpha=.71)$ (adapted from Bowles \& Babcock, 2013). For ecological validity, we framed the communal items in terms of concern for organizational relationships. While communality is a broader construct, concern for relationships is central to the communal stereotype (Bakan, 1966; Eagly, 1987). Five statements related to how immodest the employee seemed (e.g., "acted in an immodest manner") $(\alpha=.73)$. Five statements related to how materialistic the employee seemed (e.g., "is materialistic") $(\alpha=.70)$. Our dependent measure was the willingness to work with the employee (adapted from Bowles et al., 2007). It included three items asking participants how willing they would be to hire the employee and how much they would enjoy and benefit from working with her/him $(\alpha=.82)$.

The experimental materials concluded with manipulation checks on the employee's gender, whether s/he negotiated, as well as language-proficiency and demographic items. Language proficiency items included whether participants were more comfortable speaking in Arabic or English (7-point scale: 
$7=$ much more in English) and whether they attended private school before university. University interviewees had noted private education as a distinguishing factor in English-language proficiency.

\section{Results and Discussion}

Participant gender. We observed no significant effects of participant gender, and inclusion of participant gender had no effect on the pattern of results, so we removed that variable from the analysis.

Language proficiency. Participants reported feeling more comfortable speaking in Arabic than English (mean difference from mid-point $=-1.04, t[392]=12.33, p<.001$ ), but women less so than men (mean difference $=.55, t[391]=3.04, p=.003)$. Men reported attending private preparatory school more frequently than women (male $P=.23$, female $P=.13, \chi^{2}[1, N=393]=7.00, p=.008$ ). We used these variables as controls in our analyses.

Manipulation checks. Participants were significantly likely to correctly identify the employee's gender $\left(\chi^{2}[1, N=391]=309.61, p<.001\right.$ [two nonresponses] $)$ and whether the employee negotiated $\left(\chi^{2}[1, N=392]=160.66, p<.001[\right.$ one nonresponse] $)$.

Dependent measure. We used ANCOVA to test our hypotheses about the moderating effects of local employee gender and global/local employment context on willingness to work with local employees who self-advocate for higher compensation (as compared to those who did not), controlling for evaluators' Arabic/English language proficiency. Tables 3 and 4 display the ANCOVA results. Table 5 reports the estimated marginal means by condition produced by the ANCOVA reported in Table 3. Figure 4 provides a graphical illustration of the effect of negotiating on the willingness to work with the employee by employee gender and employment context.

Table 3 presents the results of ANCOVA of the full 2 (Local Employee Gender: Male/Female) $\times$ 2 (Employment Context: Global/Local) $\times 2$ (Negotiate: Yes/No) design. We observed a main effect for global/local context $\left(F[1,383]=14.90, p<.001, \eta^{2}=.04\right)$, indicating participants expressed greater willingness to work with local employees in the local than in the global context. We do not have a clear explanation for this effect. It could be a reflection of the higher regard with which local university graduates are held in local as compared to global employment contexts or a special respect for 
competitive university graduates who choose national over multinational employers. We also observed a main effect for negotiate $\left(F[1,383]=26.86, p<.001, \eta^{2}=.07\right)$, indicating that participants expressed less willingness to work with local employees who negotiated for higher compensation as compared to those who let the opportunity to negotiate pass. We discuss explanations for the effects of negotiating on the willingness to work with a local employee below with the presentation of our mediation analyses. Importantly, both of these main effects were qualified by a three-way Gender $\times$ Global/Local $\times$ Negotiate interaction effect, $F(1,383)=5.53, p=.02, \eta^{2}=.01$.

\section{[INSERT TABLES 3, 4 \& 5 APPROXIMATELY HERE]}

Table 4 displays the decomposition of this three-way interaction, testing effects of Gender $\times$ Negotiate in global and local employment contexts and effects of Global/Local $\times$ Negotiate for male and female local employees. As predicted in Hypothesis 5, reform university students expressed less willingness to work with a local employee who self-advocated for higher pay in the global employment condition, $F(1,157)=15.30, p<.001, \eta^{2}=.09$ (see top panel of Table 3 and Figure 4; negotiate estimated marginal mean $=4.99, \mathrm{SE}=.13$; no-negotiate estimated marginal mean $=5.70, \mathrm{SE}=.12$ ). As predicted in Hypothesis 6, the effect of negotiating in the local employment condition was moderated by significant interaction of Gender $\times$ Negotiate $\left(F[1,224]=5.62, p=.02, \eta^{2}=.02\right)$. As illustrated in Figure 4 and reported in the upper rows of Table 5, the reform university students expressed significantly less willingness to work with a local female employee if she negotiated for higher pay (as compared to let the opportunity to negotiate pass) in the local employment condition, $F(1,117)=18.64, p<.001, \eta^{2}=.14$. In contrast, negotiating for higher pay had no effect on the willingness to work with a local male employee in the local employment context, $F(1,105)=0.86, p=.36, \eta^{2}<.01$.

\section{[INSERT FIGURE 4 APPROXIMATELY HERE]}

As predicted in Hypothesis 7, employment context moderated the effect of negotiating on participants' willingness to work with male locals, $F(1,186)=4.09, p<.05, \eta^{2}=.02$ (see third panel of Table 4). As illustrated in Figure 4, participants were significantly less willing to work with a male local employee who negotiated for higher pay in the global employment context $\left(F[1,79]=13.38, p<.001, \eta^{2}\right.$ 
$=.15$; negotiate estimated marginal mean $=4.99, \mathrm{SE}=.18$; no-negotiate estimated marginal mean $=5.84$, $\mathrm{SE}=.17)$. In the local employment context, there was no significant effect of negotiating on the willingness to work with male employees $\left(F[1,105]=0.86, p=.36, \eta^{2}<.01\right)$. As reported in the bottom panel of Table 4, employment context did not significantly moderate the negative effect of negotiating for higher pay on the willingness to work with a local female employee $\left(F[1,195]=2.06, p=.15, \eta^{2}=.01\right)$.

In sum, this pattern of results in the decomposition of the three-way interaction effect supports our theory that low status inhibits local men's as well as local women's self-advocacy, but we still do not have a full explanation for these effects. If negotiating for higher compensation were simply a feminine norm violation, then we would expect to observe a two-way interaction effect of Gender $\times$ Negotiate and we did not (see Table 3). Another possibility is that “women don't ask” (Babcock \& Laschever, 2003), and men asking for higher pay in a global employment context appears greedy because of the relative career benefits of multinational as compared to national company employment. Our mediation analyses help us to answer these questions by exploring more deeply why participants were less inclined to work with a local man who negotiated (as compared to did not negotiate) in the global employment condition (but not in the local employment condition) and why participants were less inclined to work with a local women who negotiated in both employment conditions.

Mediation analyses. To test our hypothesized mediation effects, we followed the bootstrapping procedures advised by Hayes (2013). Bootstrapping is appropriate because our independent variables are dichotomous and we do not have a very large sample size. Therefore, we are unlikely to meet the Sobel test assumption that the product of the coefficients along the path of the indirect effect is normally distributed (Sobel, 1982).

As depicted in Figure 1, we predicted in Hypothesis 8 that perceived communality would explain the moderating effect of employment context on the willingness to work with a local male employee who self-advocates for higher pay (Hypothesis 7, supported above). We tested this moderated mediation prediction using Hayes (2013) SPSS PROCESS commands (Model 8, p. 448). The results affirmed Hypothesis 8: employing 1,000 bootstrap samples, the $95 \%$ confidence interval did not transgress zero in 
the global employment context (global bias-corrected $C I=[-.87,-.21]$ ) but did in the local employment context (local bias-corrected $C I=[-.32, .16])$. Table 6 illustrates this moderated mediation effect following Baron and Kenney's (1986) logical deduction of mediation effects.

These mediation results support our theory that locals would be less willing to work with a local male employee who negotiated for higher pay (as compared to one who did not) in the global employment context because he would appear insufficiently communal and thereby violate normative expectations of low-status behavior. In contrast, in the local employment context where local men have high status, the same negotiating behavior by a local man had no significant effect on locals' willingness to work with him or on his perceived communality. Our measures of modesty and materialism (i.e., an indicator of greed) could not explain the interaction of Global/Local $\times$ Negotiate on the willingness to work with male candidates because there were no significant interaction effects of Global/Local $\times$ Negotiate on the perceived modesty or materialism of male employees $(p s>.22)$.

As reported above and in the bottom panel Table 4, employment context did not significantly moderate the effect of negotiating for higher pay on the willingness to work with local female employees. We predicted in Hypothesis 9 that the main effect of negotiating for higher pay on the willingness to work with local female employees would be explained by a perceived lack of communality (i.e., a perceived violation of normative expectations for low-status actors), but also by a perceived lack of modesty and excessive materialism (i.e., perceived violation of feminine-specific behavioral expectations). Figure 5 illustrates our multiple mediation model for explaining the effect of self-advocating for higher pay on the willingness to work with a female local employee (adapted from Preacher and Hayes, 2008, p. 881). As compared to testing each potential mediator individually, multiple mediation has the advantages of testing for an overall mediation effect and making more transparent the extent to which each potential mediator contributes to the overall effect.

We tested for multiple mediation using Hayes (2013) SPSS PROCESS commands (Model 4, p. 445). Employing 1,000 bootstrap samples, the $95 \%$ confidence intervals for the indirect paths through the three mediators were all above zero. As predicted, participants reported lower willingness to work with a 
female local employee who negotiated because she appeared lacking in communality (bias-corrected $C I=$ $[-.37,-.05])$ and modesty (bias-corrected $95 \% C I=[-.32,-.04]$ ) and because she appeared excessively materialistic (bias-corrected 95\% $C I=[-.57,-.05]$ ). Figure 5 illustrates the multiple mediation effects following Baron and Kenney's (1986) logical deduction of mediation effects.

\section{Discussion}

The results of Study 2 mirrored the results of Study 1 and supported our hypotheses about how local men and women would be viewed if they negotiated in the global or local employment context. The results supported our theory that, for low-status men as well as women, self-advocating for higher compensation is a status violation. In the local employment condition where local men have high status, negotiating for higher pay (as compared to letting the opportunity to negotiate pass) had no significant effect on evaluators' willingness to work with a local male employee. In the global employment context in which local men are negatively stereotyped as falling short of the cosmopolitan ideal worker, negotiating for higher pay (as compared to letting the opportunity to negotiate pass) made local men appear like even less desirable employees because it made them appear insufficiently communal. Communality is a behavioral prescription of low-status actors (Conway et al, 1996; Fiske et al.; 2002 Ridgeway, 1978). Mediation analyses did not support the potential alternative analysis that negotiating for higher pay in a multinational company makes local men appear more greedy than doing so in a national company (viz., see null results above for materialism as a mediator of the effect of Global/Local $\times$ Negotiate for male local employees). Indeed, cross-cultural research in negotiation suggests that Western industrialized cultures tend to promote more individualistic and competitive negotiating behavior as compared to collectivist cultures (e.g., Lee, Oyserman, \& Bond, 2010; Ross, Xun, \& Wilson, 2002) such as those in the Arab Gulf.

As has been shown in U.S. studies, communality also explained why self-advocating for higher compensation made local evaluators less inclined to work with female local employees (Amanatullah \& Morris, 2010; Bowles et al., 2007). Extending existing research on gender in negotiation, we showed that a woman negotiating for higher pay also violated feminine-specific behavior norms. Local evaluators 
were less inclined to work with a woman who negotiated for higher compensation because it made her appear immodest and materialistic, as well as insufficiently communal. Perceived modesty and materialism did not explain the effects of negotiating on the willingness to work with a local male employee. The findings that negotiating for higher pay violates both status-based and feminine-specific behavioral norms make important contributions to the literature on gender in negotiation and help to clarify debates about whether gender effects in negotiation are at their essence about status and power differences between the sexes (Amanatullah \& Tinsley, 2013; Magee et al. 2007).

Our results support the contention that low status socially constrains male and female negotiators' potential to self-advocate, but they do not support a theoretical equation of gender with status. We find that women's self-advocacy violates not only normative expectations of low-status behavior but also gender-linked behavioral norms related to the complementarity of male and female roles (e.g., male breadwinner). Our findings fit with sociological arguments that gender is a distinctively intractable and pervasive status-linked social identity, reinforced by human reproduction (Jackman, 1994) and fundamental to human self-presentation (Ridgeway, 2011). We gain these new insights by reaching beyond the conventional "WEIRD samples" (i.e., Western, Educated, Industrialized, Rich and Democratic) (Heinrich, Heine \& Norenzayan, 2010) in negotiation research. Investigating shifts in social status at the boundaries of globalization enables novel insights into how gender and status intersect (e.g., Alvesson \& Billing, 1997; Brownell \& Wasserstrom, 2002; Bruni \& Gherardi, 2004).

\section{General Discussion}

In this research, we present qualitative and experimental data on the psychological experience of university-educated local workers from emerging economies striving to enter the global job market for managerial positions. Our findings shed light on how status and gender influence the potential for aspiring global workers to self-advocate for their career advancement. We replicate and extend the findings of U.S. based research on gender in negotiation, showing that local university-educated women are inhibited from self-advocating for higher pay by status- and gender-linked behavioral norms. We present evidence that low social status in the global employment context also inhibits local university- 
educated men from self-advocating for higher pay.

These findings are important because they suggest that negative stereotyping of local workers in global employment diminishes their sense of agency in career advancement. If global workers believe they must self-present in ways that hew to the constraints of their low status, they risk contributing to a self-fulfilling prophecy that reinforces their place in the status hierarchy below cosmopolitan employees. As has been illuminated in extensive research on the "double bind" for women (Phelan, Moss-Racusin \& Rudman, 2008), the answer is unlikely to be that locals should simply defy prescriptive stereotypes for low-status workers by behaving in more agentic or self-promoting ways. More research is needed to understand how low-status men, in general, and locals in global corporations, more specifically, can effectively navigate their career advancement in ways that help them to overcome negative stereotyping and subordinating social constraints (Livingston \& Pearce, 2009; Thomas \& Gabarro, 1999).

Employing experimental methods focused on the psychological experience of the global employment market for locals, this research contributes a novel perspective to the growing body of archival and ethnographic studies documenting the international hierarchy of workers in the global employment market (Carr et al., 2010; Leonardi \& Rodriguez-Lluesma, 2014; Metiu, 2006; Neeley, 2013; Rissing \& Castilla, 2014). Much of the organizational research documenting and theorizing status dynamics between local and more cosmopolitan workers stems from deep investigations of individual multi-national enterprises (e.g., Leonardi \& Rodriguez-Lluesma, 2014; Metiu, 2006; Neeley, 2013). Our research suggests that the psychological experience of local status extends beyond direct intraorganizational experiences (e.g., differential treatment or pay) to shape the pursuit of employment in global enterprise by local job candidates — even job candidates trained in university environments focused on preparation for global business employment. Our work also adds experimental evidence to qualitative investigations of how globalization is shaping the construction of multiple masculinities and challenging the social status of men from non-Western economies (Beasley, 2008; Connell, 1998; Connell \& Messerschmidt, 2005).

Our findings that classic gender effects in negotiation are moderated by men's relative status in 
context underline the importance of studying intersecting gender identities (e.g. Acker, 2012; Ayres \& Siegelman, 1995). Gender effects on social behavior are fundamentally contextual, reflective of the "distal" influences of the social structure of gender relations but also of "proximal" cues embedded in the specific situation of interaction (Deaux \& LaFrance, 1998). By applying an intersectional lens to gender identities, we demonstrate how the gender status hierarchy is not fixed across contexts but can be shaped by other identities that are also relevant to social and material dynamics in negotiation.

\section{Limitations and Directions for Future Research}

Our experimental methods have weaknesses. In contrast to archival or field-based observational methods, we have no direct observations of status-linked social behaviors in actual workplace interactions. We are capturing psychological reactions to social situations. We cannot say with certainty how these psychological reactions would be acted upon in actual negotiation situations, nor how hiring managers would respond.

This research has the strength of stretching beyond "WEIRD" psychological samples (Heinrich et al, 2010) and beyond the most commonly studied spaces of global work (e.g., Europe, China, India). But more research is needed to understand the ladder of status hierarchy in global employment (Rissing \& Castilla, 2014). For instance, the patterns we observe in our research might not apply to the job markets of the "Asian Tigers" (e.g., Singapore, South Korea) where nationals claim credit for homegrown global economic ascendance. A deeper understanding of socioeconomic factors that moderate the psychological experience and challenges of global-local biculturalism would advance both theory and practice (e.g., see qualitative studies by Erez \& Gati, 2004; Gillespie, McBride, \& Riddle, 2010).

Just as research has sought to uncover how women in the United States can avoid backlash when advocated for themselves through relational accounts (Bowles \& Babcock, 2013), future studies might address the conditions under which locals can escape the penalties of self-advocacy. For local men negotiating in global work contexts, studies could explore how to appear communal yet still-self advocate. For local women negotiating in a local work context, studies could additionally explore how to self-advocate in ways that deflect immodesty and materialism proscriptions. It is also worth testing what 
types of "cosmopolitan" identity markers, such as Western university degrees, or employment experiences mitigate the social constraints of "local" worker identities in multinational employment contexts.

Motivated by the current findings, more research could be done with global hiring managers and locals aspiring to employment in the global job market to understand more deeply locals' barriers to entry, integration, and career advancement in multinational corporations. Insights and inspiration could be gained from the expansive literature on women's career corporate advancement (Ely, Ibarra \& Kolb, 2011; Ibarra, 2011), from diversity studies that have yet to include locals in global employment as a marginalized category, or from research on organizational nudges for more equitable organizations (e.g., Bohnet, 2016). We would also welcome future research on negotiations beyond salary. We wonder, for example, if locals might have a higher propensity than their cosmopolitan counterparts to negotiate for training or other development opportunities, given the pervasive stereotype that they are less qualified and competent. This might be particularly true for candidates who do not have the English-speaking university credential that those in our experimental studies did. This work would ideally employ multiple methods iterating between deep field explorations for theory generation and experimental tests of hypotheses (Chatman \& Flynn, 2005).

\section{Conclusion}

Our research provides a window into the psychological experience of job applicants in emerging economies striving for cosmopolitan status in a globalized world. Illuminating the experience of locals highlights one of the many ways in which globalization may reinforce inequalities and institutionalize certain kinds of privilege. More experimental and organizationally-grounded research is needed to refine our theoretical understanding of the status hierarchies in global employment and their distributional and performance implications. As organizations become increasingly global, we hope that scholars will continue to illuminate mechanisms of inequality, thus illustrating how individuals and organizations can extend more equal opportunities through work around the world. 


\section{References}

Abu-Lughod, L. (1998). Remaking women: Feminism and modernity in the Middle East. Princeton, N.J.: Princeton University Press.

Acker, J. (1990). Hierarchies, Jobs, Bodies: A Theory of Gendered Organizations. Gender and Society, $4(2), 139-158$.

Acker, J. (2012). Gendered organizations and intersectionality: Problems and possibilities. Equality, Diversity and Inclusion: An International Journal, 31(3), 214-224.

Ahmed, F. E. (2004). The rise of the Bangladesh garment industry: Globalization, women workers, and voice. NWSA journal, 16(2), 34-45.

Al-Munajjed, M. (1997). Women in Saudi Arabia today. New York: Macmillan/St. Martin's Press.

Al-Ali, J. (2008). Emiratisation: Drawing UAE nationals into their surging economy. International Journal of Sociology and Social Policy, 28(9/10), 365-379.

Al-Waqfi, M., \& Forstenlechner, I. (2010). Stereotyping of citizens in an expatriate-dominated labour market: Implications for workforce localisation policy. Employee Relations, 32(4), 364-381.

Alvesson, M., \& Billing, Y. D. (1997). Masculinities, femininities, and work. Understanding gender and organizations (pp. 82-102). London: Sage Publications.

Amanatullah, E. T., \& Morris, M. W. (2010). Negotiating gender roles: Gender differences in assertive negotiating are mediated by women's fear of backlash and attenuated when negotiating on behalf of others. Journal of Personality and Social Psychology, 98(2), 256-267.

Amanatullah, E. T. \& Tinsley, C. H. (2013). "Ask and ye shall receive? How gender and status moderate negotiation success.” Negotiation and Conflict Management Research, 6(4): 253-272.

Aneesh, A. (2012). Negotiating globalization: Men and women of India's call centers. Journal of Social Issues, 68(3), 514-533.

Arab Labor Organization. (2010). The conditions of labor and employment in the Arab Countries.

Arnett, J. J. (2002). The psychology of globalization. American Psychologist, 57(10), 774-783. 
Ayres, I., \& Siegelman, P. (1995). Race and gender discrimination in bargaining for a new car. American Economic Review, 85(3), 304-321.

Babcock, L., Gelfand, M., Small, D., \& Stayn, H. (2006). Gender differences in the propensity to initiate negotiations. In D. D. Cremer, M. Zeelenberg, \& J. K. Murnighan (Eds.), Social Psychology and Economics (pp. 239-262). Mahwah, NJ: Lawrence Erlbaum.

Babcock, L., \& Laschever, S. (2003). Women don't ask. Princeton, NJ: Princeton University Press.

Bakan, D. (1966). The duality of human existence. Chicago: Rand McNally.

Barley, S. R. (1991). Contextualizing conflict: Notes on the anthropology of disputes and negotiations. In M. H. Bazerman, B. H. Sheppard, \& R. Lewicki (Eds.), Research on Negotiation in Organizations (Vol. 3, pp. 165-199). Greenwich, CT: JAI Press.

Baron, R. M., \& Kenney, D. A. (1986). The moderator-mediator variable distinction in social psychological research: Conceptual, strategic and statistical considerations. Journal of Personality and Social Psychology, 51, 1173-1182.

Beasley, C. (2008). Rethinking Hegemonic Masculinity in a Globalizing World. Men and Masculinities, 11(1), 86-103. doi:10.1177/1097184x08315102

Biernat, M. (2003). Toward a broader view of social stereotyping. American Psychologist, 58(12), 10191027.

Biernat, M., Manis, M., \& Nelson, T. E. (1991). Stereotypes and standards of judgment. Journal of Personality and Social Psychology, 60(4), 485-499.

Bohnet, I. (2016). What Works: Gender Equality by Design. Harvard University Press.

Bowles, H. R., \& Babcock, L. (2013). How can women escape the compensation negotiation dilemma? Relational accounts are one answer. Psychology of Women Quarterly, 37(1), 80-96.

Bowles, H. R., Babcock, L., \& Lai, L. (2007). Social incentives for gender differences in the propensity to initiate negotiations: Sometimes it does hurt to ask. Organizational Behavior and Human Decision Processes, 103(1), 84-103. 
Bowles, H. R., \& McGinn, K. L. (2008). Untapped potential in the study of negotiation and gender inequality in organizations. In J. P. Walsh \& A. Brief (Eds.), Academy of Management Annals (Vol. 2, pp. 99-132). Philadelphia: Routledge Taylor \& Francis Group.

Brass, D. J. (1985). Men's and women's networks: A study of interaction patterns and influence in an organization. Academy of Management Journal, 28(2), 327-343.

Brown, P., \& Levinson, S. C. (1987). Politeness: Some universals in language use. Cambridge, UK: Cambridge University Press.

Brownell, S., \& Wasserstrom, J. N. (2002). Chinese femininities, Chinese masculinities: A reader. Berkeley: University of California Press.

Bruni, A., \& Gherardi, S. (2004). Doing gender, doing entrepreneurship: An ethnographic account of intertwined practices. Gender, Work and Organization, 11(4), 406.

Buda, Richard and Elsayed-Elkhouly, Sayed. (1988). Cultural Differences between Arabs and Americans: Individualism-Collectivism Revisited. Journal of Cross-Cultural Psychology (29) 3. 487-492.

Carr, S. C. (2010). Aid salary discrepancies and development workers' performance: Full Research Report ESRC End of Award Report. Retrieved from Swindon, UK.

Carr, S. C., MacLachlan, M., \& Chipande, R. (1998). Expatriate aid salaries in Malaŵi: A doubly demotivating influence? International Journal of Educational Development, 18(2), 133-143.

Chatman, J. A., \& Flynn, F. J. (2005). Full-cycle micro-organizational behavior research. Organization Science, 16(4), 434-447.

Choi, J., \& Chen, C. C. (2007). The relationships of distributive justice and compensation system fairness to employee attitudes in international joint ventures. Journal of Organizational Behavior, 28, $687-703$.

Connell, R. W. (1998). Masculinities and globalization. Men and Masculinities, 1(1), 3-23.

Connell, R. W., \& Messerschmidt, J. W. (2005). Hegemonic masculinity: Rethinking the concept. Gender and Society, 19(6), 829-859. 
Cook, K. S. (1975). Expectations, evaluations and equity. American Sociological Review, 372-388.

Cuddy, A. J., Wolf, E. B., Glick, P., Crotty, S., Chong, J., \& Norton, M. I. (2015). Men as cultural ideals: Cultural values moderate gender stereotype content. Journal of personality and social psychology, 109(4), 622.

De Dreu, C. K. W., \& Gelfand, M. J. (Eds.). (2007). The psychology of conflict and conflict management in organizations. San Francisco: Jossey Bass.

Deaux, K., \& LaFrance, M. (1998). Gender. In D. T. Gilbert, S. Fiske, \& G. Lindsey (Eds.), The handbook of social psychology (4th ed., pp. 788-827). Boston: McGraw-Hill.

Dreher, G. F., \& Cox Jr, T. H. (2000). Labor market mobility and cash compensation: The moderating effects of race and gender. Academy of Management Journal, 43(5), 890-900.

Dreher, G. F., \& Cox, T. H., Jr. (1996). Race, gender, and opportunity: A study of compensation attainment and the establishment of mentoring relationships. Journal of Applied Psychology, 81(3), 297-308.

Eagly, A. H. (1987). Sex differences in social behavior: A social-role interpretation. Hillsdale, NJ: Erlbaum.

Ely, R. J., Ibarra, H., \& Kolb, D. M. (2011). Taking gender into account: Theory and design for women's leadership development programs. Academy of Management Learning \& Education, 10(3), 474493.

Erez, M., \& Gati, E. (2004). A dynamic, multi-level model of culture: From the micro level of the individual to the macro level of a global culture. Applied Psychology: An International Review, $53(4), 583-598$.

Erez, M., \& Shokef, E. (2008). The culture of global organizations. In P. B. Smith, M. F. Peterson, \& D. C. Thomas (Eds.), The handbook of cross-cultural management research (pp. 285-300). Los Angeles. 
Fiske, S.T., A.J.C. Cuddy, P. Glick, and J. Xu. “A Model of (Often Mixed) Stereotype Content:

Competence and Warmth Respectively Follow from Status and Competition" Journal of Personality and Social Psychology 82, no. 6 (June 2002): 878-902.

Forstenlechner, I. Madi, M., Selim, H., and Rutledge, E. (2012) Emiratisation: determining the factors that influence the recruitment decisions of employers in the UAE. The International Journal of Human Resource Management.23(2), 406-421.

Freeman, C. (2001). Is Local: Global as Feminine: Masculine? Rethinking the Gender of Globalization. Signs: Journal of Women in Culture \& Society, 26(4), 1007.

Fu, J. H.-Y., \& Chiu, C.-Y. (2007). Local culture's responses to globalization: Exemplary persons and their attendant values. Journal of Cross-Cultural Psychology, 38(5), 636-653.

Gillespie, K., McBride, J. B., \& Riddle, L. (2010). Globalization, biculturalism and cosmopolitanism: The acculturation status of Mexicans in upper management. International Journal of Cross Cultural Management, 10(1), 37-53.

Graham, P. (Ed.) (1995). Mary Parker Follett--Prophet of management: A celebration of writings from the 1920s. Boston, MA: Harvard Business School Press.

Greig, F, Hausmann, R, Tyson, L D and Zahidi, S. The Global Gender Gap Report 2015.Geneva: World Economic Forum.

Haas, M. R. (2006). Acquiring and applying knowledge in transnational teams: The roles of cosmopolitans and locals. Organization Science, 17(3), 367-384.

Haddad, Y. Y., \& Esposito, J. L. (1998). Islam, gender, and social change. New York: Oxford University Press.

Harb, C., \& Smith, P. B. (2008). Self-construals across cultures: Beyond independence-interdependence. Journal of Cross-Cultural Psychology, 39(2), 178-197.

Harrod, W. J. (1980). Expectations from unequal rewards. Social Psychology Quarterly, 126-130. 
Heilman, M. E. (1983). Sex bias in work settings: The lack of fit model. In B. M. Staw \& L. I. Cummings (Eds.), Research in Organizational Behavior (Vol. 5, pp. 269-298). Greenwich, CT: JAI.

Heinrich, J., Heine, S. J., \& Norenzayan, A. (2010). Most people are not WEIRD. Nature, 466, 29. Hong, Y.-y., Wan, C., No, S., \& Chiu, C.-y. (2007). Multicultural identities. In S. Kitayama \& D. Cohen (Eds.), Handbook of cultural psychology. (pp. 323-345). New York, NY US: Guilford Press. Hudson, M. (2006). The Gulf engulfed: Confronting globalization "American-style”. In J. Fox, N. M. Sabbah, \& M. A. Mutawa (Eds.), Globalization and the Gulf (pp. 148-162). London: Routledge. Ibarra, H. (2011). Taking Gender into Account: Theory and Design for Women's Leadership Development Programs, Academy of Management Learning and Education. (Vol 10, No. 3) pp. 474-493.

International Labor Organization. (2014). Maternity and paternity at work: Law and practice across the world (pp. 1-204).

Jackman, M. R. (1994). The velvet glove: Paternalism and conflict in gender, class, and race relations. Berkeley, CA: University of California Press.

Kanter, R.M. (1995). World Class: Thriving Locally in the Global Economy. Simon and Shuster, New York.

Katz, D., \& Kahn, R. L. (1966). The social psychology of organizations (2nd ed.). New York: Wiley. Kemmelmeier, M., \& Cheng, B. Y.-M. (2004). Language and self-sonstrual priming: A replication and extension in a Hong Kong sample. Journal of Cross-Cultural Psychology, 35, 705-712.

Lee, S. W. S., Oyserman, D., \& Bond, M. (2010). Am I doing better than you? That depends on whether you ask me in English or Chinese: Self-enhancement effects of language as a cultural mindset prime. Journal of Experimental Social Psychology, 46, 785-791.

Leung, K., Zhu, Y., \& Ge, C. (2009). Compensation disparity between locals and expatriates: Moderating the effects of perceived injustice in foreign multinationals in China. Journal of World Business, $44(1), 85-93$. 
Livingston, R. W., \& Pearce, N. A. (2009). The Teddy-Bear Effect Does Having a Baby Face Benefit Black Chief Executive Officers?. Psychological Science, 20(10), 1229-1236.

MacLachlan, M., Carr, S. C., \& E., McCauliffe. (2010). The aid triangle: Recognising the human dynamics of dominance, justice, and identity. London: Zed Books.

Markus, H. R., \& Kitayama, S. (1991). Culture and the self: Implications for cognition, emotion, and motivation. Psychological Review, 98(2), 224-253.

McMillan, M., Rodrik, D., \& Verduzco-Gallo, Í. (2014). Globalization, structural change, and productivity growth, with an update on Africa. World Development, 63(1), 11-32.

Mellahi, K. (2007). The Effect of Regulations on HRM: Private Sector Firms in Saudi Arabia, International Journal of Human Resource Management, 18(1), 85-99.

Metcalfe, B. (2006). Exploring cultural dimensions of gender and management in the Middle East. Thunderbird International Business Review, 48(1), 93-107.

Metcalfe, B. (2007). Gender and human resource management in the Middle East. International Journal of Human Resource Management, 18(1), 54-74.

Metiu, A. (2006). Owning the code: Status closure in distributed groups. Organization Science, 17(4), 418-435.

Metle, M. A. K. (2002). The influence of traditional culture on attitudes towards work among Kuwaiti women employees in the public sector. Women in Management Review, 17(6), 245-261.

Miller, J., Lincoln, J. R., \& Olson, J. (1981). Rationality and equity in professional networks: Gender and race as factors in the stratification of interorganizational systems. American Journal of Sociology, $87(2), 308-335$.

Neeley, T. (2012). Global business speaks English: Why you need a language strategy now. Harvard Business Review, 90(5), 116-124. 
Neeley, T. B. (2013). Status loss and achieved status distinctions in global organizations. Organization Science, 24(2), 476-497.

Neeley, T., \& Kaplan, R. S. (2014). What's your language strategy? It Should Bind Your Company’s Global Talent Management and Vision. Harvard Business Review, 92(9), 70-76.

Ng, C., \& Mitter, S. (2005). Valuing Women's Voices Call Center Workers in Malaysia and India. Gender, Technology and Development, 9(2), 209-233.

Oyserman, D. (2011). Culture as situated cognition: Cultural mindsets, cultural fluency, and meaning making. European review of social psychology, 22(1), 164-214.

Pfeffer, J. (1981). Power in organizations. Boston, MA: Pitman.

Phelan, J. E., Moss-Racusin, C. A., \& Rudman, L. A. (2008). Competent yet out in the cold: Shifting criteria for hiring reflect backlash toward agentic women. Psychology of Women Quarterly, 32(4), 406-413.

Preacher, K. J., \& Hayes, A. F. (2004). SPSS and SAS procedures for estimating indirect effects in simple mediation models. Behavior Research Methods, 36(4), 717-731.

Preacher, K. J., \& Hayes, A. F. (2008). Asymptotic and resampling strategies for assessing and comparing indirect effects in multiple mediator models. Behavior Research Methods, 40(3), 879-891.

Preacher, K. J., Rucker, D. D., \& Hayes, A. F. (2007). Addressing moderated mediation hypotheses: Theory, methods, and prescriptions.

Ramady, M. A. (2005). The Saudi Arabian economy: Springer Science \& Business Media, Inc.

Rees, C., Mamman, A., and Bin Braik, A. (2007) Emiratization as a strategic HRM change initiative: case study evidence from a UAE petroleum company. International Journal of Human Resource Management. 18(1), 33-53. 
Ridgeway, C. L. (1987). Nonverbal behavior, dominance, and the basis of status in task groups. American Sociological Review, 683-694.

Ridgeway, C. L. (2001). How do status beliefs develop? The role of resources and interactional experiences. In J. Jost \& B. Major (Eds.), The psychology of legitimacy: Emerging perspectives on ideology, justice and intergroup relations (pp. 357-377). Cambridge, England: Cambridge University Press.

Ridgeway, C. L. (2011). Framed by gender: How gender inequality persists in the modern world. Oxford, UK: Oxford University Press.

Ridgeway, C. L., Boyle, E. H., Kuipers, K. J., \& Robinson, D. T. (1998). How do status beliefs develop? The role of resources and interactional experience. American Sociological Review, 63(3), 331350.

Ridgeway, C. L., \& Erickson, K. G. (2000). Creating and spreading status beliefs. American Journal of Sociology, 106(3), 579-615.

Rissing, B., and Castilla, E.( 2014). House of Green Cards: Statistical or Preference-Based Inequality in the Employment of Foreign Nationals. American Sociological Review 79 (6): 1226-1255.

Ross, M., Xun, W. E., \& Wilson, A. E. (2002). Language and the bicultural self. Personality and Social Psychology Bulletin, 28(8), 1040-1050.

Roxburgh, C., Dorr, N., Leke, A. Tazi-Riffi, A., Wamelen, A., Lund, S. Chironga, M., Alatovik, T., Atkins, C., Terfous, N., Zeino-Mahmalat, T. (2010). Lions on the move: The progress and potential of African economies. McKinsey Global Institute.

Saliba, T., Allen, C., \& Howard, J. A. (2002). Gender, politics, and Islam. Chicago: University of Chicago Press.

Sanchez-Burks, J., \& Lee, F. (2007). Cultural psychology of workways. In S. Kitayama \& D. Cohen (Eds.), Handbook of cultural psychology. (pp. 346-369). New York, NY US: Guilford Press. 
Small, D. A., Gelfand, M., Babcock, L., \& Gettman, H. (2007). Who goes to the bargaining table? The influence of gender and framing on the initiation of negotiation. Journal of Personality and Social Psychology, 93(4), 600-613. doi:10.1037/0022-3514.93.4.600

Sobel, M. E. (1982). Asymptotic intervals for indirect effects in structural equations models. In S. Leinhart (Ed.), Sociological methodology (pp. 290-312). San Francisco: Jossey-Bass.

Stewart, P. A., \& Moore Jr, J. C. (1992). Wage disparities and performance expectations. Social Psychology Quarterly, 78-85.

The World Bank. (2013). Opening Doors: Gender Equality and Development in the Middle East and North Africa, 1-209.

Thomas, D. A., \& Gabarro, J. J. (1999). Breaking through: The making of minority executives in corporate america. Boston, MA: Harvard Business School Press.

Tong, Y. Y., Hong, Y. Y., Lee, S. L., \& Chiu, C. Y. (1999). Language use as a carrier of social identity. International Journal of Intercultural Relations, 23(2), 281-296.

van de Vijver, F. J. R. (2001). The evolution of cross-cultural research methods. In D. Matsumoto (Ed.), The Handbook of Culture and Psychology (pp. 77-97). London: Oxford University Press.

Weber, M. (1968). Economy and society (E. Frischoff, Trans.). New York: Bedminister Press.

Zhang, S., Morris, M. W., Cheng, C. Y., \& Yap, A. J. (2013). Heritage-culture images disrupt immigrants' second-language processing through triggering first-language interference. Proceedings of the National Academy of Sciences, 110(28), 11272-11277. 


\section{Footnotes}

${ }^{1}$ Our use of the terms "cosmopolitan" and "local differs from Haas (2006) in one respect. As Haas (2006) defines the terms, "Cosmopolitans are identified as individuals who have lived and worked in multiple countries and who speak several languages, whereas locals are identified as individuals who have lived and worked in the project country and who speak the local language" (p. 369, italics added). We found in our research that "cosmopolitan" or "local" status was defined less by the number of languages one spoke than by one's command of English as the language of international business. For instance, African job candidates might speak numerous languages of their home regions, but lack command of English and therefore appear "local." Whereas British or American candidates might only speak English fluently, but appear "cosmopolitan" if they had substantial international work experience.

${ }^{2}$ In the Arab Gulf countries such as Saudi Arabia and the United Arab Emirates (UAE), foreign workers occupy more than 80 percent of private-sector jobs (Arab Labor Organization, 2010). English has become the lingua franca of the private sector in place of Arabic. As the minority amidst a foreign worker majority, Gulf nationals face pressure to adapt to and integrate themselves within the new global labor market (Al-Ali, 2008; Al-Waqfi \& Forstenlechner, 2010; Ramady, 2005). This has led to a growing body of research in the Gulf region on the employment of nationals in the private sector (aka "nationalization"). This literature documents the widespread stereotyping of nationals as lacking a strong work ethic and the skills needed to succeed in a globally competitive enterprise (Al-Ali, 2008; Al-Waqfi \& Forstenlechner, 2010; Ramady, 2005).

${ }^{3}$ Sub-Saharan Africa is a massive emerging market. It had hung in the margins of the global economy, until the 1980s when most of its national governments undertook liberalizing reforms. Phasing out restrictions on imports, slashing tariffs, and encouraging foreign direct investment and exports opened the region up to rapid economic globalization (McMillan, Rodrik \& Verduzco-Gallo, 2014). Since the lifting of Apartheid and the subsequent end of international sanctions, South Africa has played an important role in Sub-Saharan Africa's entry into the global economy. South Africa experienced annual growth rates approaching five percent in the first decade of the $21^{\text {st }}$ century (Statistics South Africa, 2011). Even though only 9.6 percent of the population speak English at home as their native language, English is becoming the lingua franca of its international business (Statistics South Africa, 2011). 


\section{Appendix \\ Multi-Item Measures Created for Studies 1 and 2}

$\underline{\text { Study } 1}$

Wasta I would need the recommendation of wasta in this job situation.

I would need a connection to get this job.

I would only get offered a job through wasta.

Wasta is only way to secure job offer in such a situation.

$\underline{\text { Study } 2}$

Communal

Hamad/Hamda clearly cares about relationships.

Hamad/Hamda puts people first.

Hamad/Hamda enjoys working with other people.

Having good relationships with colleagues is important to Hamad/Hamda.

Hamad/Hamda talks too much. (Arabic expression; reverse coded)

Modest

Hamad/Hamda is modest.

Hamad/Hamda displays the appropriate level of modesty.

Hamad/Hamda acted in an immodest manner. (reverse coded)

Hamad/Hamda is respectful toward his/her seniors.

Hamad/Hamda doesn't know when to stop. (Arabic expression; reverse coded)

Materialistic Hamad/Hamda is materialistic.

Hamad/Hamda is threatening to leave the company in order to get more money.

Hamad/Hamda's negotiating behavior is aggressive.

Hamad/Hamda is pressuring the company to pay him/her more.

Hamad/Hamda is giving up a lot on his/her demands. (reverse coded) 
Table 1. Representative Descriptions of "Ideal" and "Local" Workers in by Hiring Managers in the

\section{Global Job Markets of the United Arab Emirates and the Republic of South Africa}

Descriptions of "Ideal" Workers

English Language Competence
- "English is important and business English is a
given. Having another language shouldn't ove
look your ability to speak English. Language
competency is correlated with skill sets like
financial knowledge." [UAE, Multinational
Bank]

- "Interacting with clients is very important because we can't have someone that we put, even at a junior level, in front of a client that isn't able to converse very easily [in English]." [South Africa, Multinational Consulting]

International Experience, particularly in Western markets

- "There are people who thrive when they get here straightaway, and that tends to be people who have studied abroad... Sometimes, we can get people who have done their undergrad at AUB and then gone on and done their master's in the U.K." [UAE, Multinational Consulting]

- "When we...bring employees in from, say, the U.K., they come with a different perspective. ... I guess it's a bit trite to say it, but they have a more of a global feel. They've been in tougher ...consumer environments... You might get away with it in an emerging market; if you do that in the middle of the U.K., you're going to kill yourself in the market quickly... Back to the question... these global people bring... best practices. [South Africa, Multinational Consumer Goods]

- "So, what's the ideal? ... He's best-in-class in terms of what the function is, be it finance, manufacturing, marketing, whatever, HR, and has practiced that craft in more than one market or region... If they've worked both in an emerging and a developed market, they have a different perspective... If someone's African but...they've spent four... or three years in the U.K. business and then a year in Asia, and then come back, they have a completely different perspective." [South Africa, Multinational Executive Search]

\section{Low-Status Local Worker Descriptors} Lack of Competence and Work Ethic

- [After describing the ideal global worker,] "The pool we get for local hires is different. The candidates are, well, not really at that level." [UAE, Multinational Tech]

- "I guess it falls under work ethic... It is really difficult for us to find locals fitting our expectations. It is not intellectual ability; it is around work ethic expectations. Getting those bad habits out of them is a lot of work. I need someone to hit the ground running, but I need to spend time getting bad habits out of them, it is that much more stressful for me." [South Africa, Multinational Financial Services]

\section{Lack of Native English Competence}

- "We find that, obviously, English wasn't their first language, and so communication is the first barrier that they have coming into a workforce that's mostly English-speaking... And if you struggle to communicate just with us or your client, it's difficult to sell." [South Africa, Multinational Consulting]

\section{Lack of International Experience}

- "The challenges we face [recruiting in the region] are sometimes just to do with it not being a very developed market or a developed student, you know, in terms of them having the savvy to book a flight and their hotel to come for an interview. Like, even down to basic logistic things that we find we have to do a lot more assisting here than we would... They do seem to be less mature and less kind of savvy, I guess, streetwise, I mean, than perhaps counterparts who are studying elsewhere." [UAE, Multinational Consulting]

- "If you're interacting with a client who has lived on three continents and you have only lived in Nigeria, it's harder to relate." [South Africa, Multinational Consulting Firm] 
Table 2. Study 1: Ordered Logistic Regression of the Propensity to Negotiate for Higher

Compensation, Testing Effects of Local (vs. Global) and Male (vs. Female) Job Candidate ( $\mathbf{N}=157)$

\begin{tabular}{lcccc} 
& \multicolumn{2}{c}{${\text { Model } 1^{\mathrm{a}}}$} & \multicolumn{2}{c}{ Model 2 } \\
\hline & $\mathrm{B}$ & $\operatorname{Exp}(\mathrm{b})$ & $\mathrm{b}$ & $\operatorname{Exp}(\mathrm{b})$ \\
\hline Local & $1.59^{* * *}$ & $4.89^{* * *}$ & $0.88^{\mathrm{T}}$ & $2.42^{\mathrm{T}}$ \\
Male & & & -0.46 & 0.63 \\
Local $\times$ Male & & & $1.49^{*}$ & $4.43^{*}$ \\
\hline
\end{tabular}

Note: $\mathrm{b}=\log$ odds, $\operatorname{Exp}(\mathrm{b})=$ Odds Ratio.

${ }^{\mathrm{a}}$ Likelihood Ratio $\chi^{(1, \mathrm{n}=157)}=24.32, p<.001$

${ }^{\mathrm{b}}$ Likelihood Ratio $\chi^{(3, \mathrm{n}=157)}=31.10, p<.001$

${ }^{\mathrm{T}} p=.07 .{ }^{*} p=.03 .^{* * *} p<.001$. 
Table 3. Study 2: ANCOVA of Willingness to Work with Employee, Testing Effects of Global/Local Employment Context, Employee Gender, and Negotiate (Yes/No) Conditions and Controlling for Participants' Arabic/English Language Proficiency $(\mathrm{N}=393)$

\begin{tabular}{lcccc}
\hline Source & df & MS & F & $\eta^{2}$ \\
\hline Gender of Employee & 1 & 0.002 & 0.001 & $<.001$ \\
Global/Local Context & 1 & 20.01 & $14.90^{* * *}$ & .04 \\
Negotiate (Yes/No) & 1 & 36.08 & $26.86^{* * *}$ & .07 \\
Gender $\times$ Global/Local & 1 & 0.43 & 0.32 & .001 \\
Gender $\times$ Negotiate & 1 & 0.80 & 0.59 & .002 \\
Global/Local $\times$ Negotiate & 1 & 0.21 & 0.16 & $<.001$ \\
Gender $\times$ Global/Local $\times$ Negotiate & 1 & 7.42 & $5.53^{*}$ & .01 \\
Controls: Comfort in Arabic/English & 1 & 10.60 & $7.89^{* *}$ & .02 \\
$\quad$ Private High School & 1 & 7.22 & $5.37^{*}$ & .01 \\
Error & 383 & 1.34 & & \\
\hline
\end{tabular}

Note. Italics indicate controls for language proficiency. ${ }^{*} p<.05 .{ }^{* *} p<.01 .^{* * *} p<.001$. 
Table 4. Study 2: Decomposition of Three-way Interaction of Gender $\times$ Global/Local $\times$ Negotiate (in Table 2), Presenting ANCOVA Tests of Global/Local $\times$ Negotiate for Male and Female Employees and Gender $\times$ Negotiate in Global and Local Employment Contexts

Global Employment Context

\begin{tabular}{lcccc}
\hline Source & df & MS & F & $\eta^{2}$ \\
\hline Gender of Employee & 1 & 0.24 & 0.18 & .001 \\
Negotiate (Yes/No) & 1 & 19.89 & $15.30^{* * *}$ & .09 \\
Gender $\times$ Negotiate & 1 & 1.35 & 1.04 & .01 \\
Controls: Comfort in Arabic/English & 1 & 3.85 & 2.97 & .02 \\
$\quad$ Private High School & 1 & 9.95 & $7.66^{* *}$ & .05 \\
Error & 157 & 1.30 & & \\
\hline
\end{tabular}

Local Employment Context

\begin{tabular}{lcccc}
\hline Source & $\mathrm{df}$ & $\mathrm{MS}$ & $\mathrm{F}$ & $\eta^{2}$ \\
\hline Gender of Employee & 1 & 0.27 & 0.19 & .001 \\
Negotiate (Yes/No) & 1 & 17.80 & $13.00^{* * *}$ & .06 \\
Gender $\times$ Negotiate & 1 & 7.70 & $5.62^{*}$ & .02 \\
Controls: Comfort in Arabic/English & 1 & 6.06 & $4.43^{*}$ & .02 \\
$\quad$ Private High School & 1 & 0.76 & 0.56 & .002 \\
Error & 224 & 1.37 & & \\
\hline
\end{tabular}

Male Employee

\begin{tabular}{lcccc}
\hline Source & df & MS & F & $\eta^{2}$ \\
\hline Global/Local Context & 1 & 7.77 & $5.81^{*}$ & .03 \\
Negotiate (Yes/No) & 1 & 14.24 & $10.65^{* *}$ & .05 \\
Global/Local × Negotiate & 1 & 5.47 & $4.09^{*}$ & .02 \\
Controls: Comfort in Arabic/English & 1 & 8.04 & $6.02^{*}$ & .03 \\
& 1 & 8.92 & $6.67^{*}$ & .04 \\
Error & 186 & 1.34 & & \\
\hline
\end{tabular}

Female Employee

\begin{tabular}{lcccc}
\hline Source & $\mathrm{df}$ & $\mathrm{MS}$ & $\mathrm{F}$ & $\eta^{2}$ \\
\hline Global/Local Context & 1 & 12.67 & $9.39^{* * *}$ & .05 \\
Negotiate (Yes/No) & 1 & 21.61 & $16.03^{* * *}$ & .08 \\
Global/Local × Negotiate & 1 & 2.78 & 2.06 & .01 \\
Controls: Comfort in Arabic/English & 1 & 3.39 & 2.51 & .01 \\
$\quad$ Private High School & 1 & 0.86 & 0.64 & .003 \\
Error & 195 & 1.35 & & \\
\hline
\end{tabular}

${ }^{*} p<.05 .{ }^{* *} p<.01 .^{* * *} p<.001$. 
Table 5. Study 2: Estimated Marginal Mean Willingness to Work with Local Employee, Generated by ANCOVA (in Table 3) Testing Effects of Global/Local Employment Context, Employee Gender, and Negotiate (Yes/No) Conditions and Controlling for Participants' Arabic/English Language Proficiency

\begin{tabular}{|c|c|c|c|c|}
\hline \multirow[b]{2}{*}{ Context } & & & \multicolumn{2}{|c|}{ Employee } \\
\hline & & & Male & Female \\
\hline \multirow[t]{7}{*}{ Local } & No Negotiate & mean & 5.85 & $6.29^{\mathrm{a}}$ \\
\hline & & SE & $(.16)$ & $(.16)$ \\
\hline & & $\mathrm{n}$ & 53 & 55 \\
\hline & Negotiate & mean & 5.65 & 5.34 \\
\hline & & SE & $(.16)$ & (.14) \\
\hline & & $\mathrm{n}$ & 56 & 66 \\
\hline & Local: Mean d & erence & 0.20 & $0.95^{* *}$ \\
\hline \multirow[t]{7}{*}{ Global } & No Negotiate & mean & 5.78 & 5.52 \\
\hline & & SE & $(.18)$ & $(.17)$ \\
\hline & & $\mathrm{n}$ & 43 & 45 \\
\hline & Negotiate & mean & 4.92 & 5.04 \\
\hline & & SE & $(.18)$ & $(.20)$ \\
\hline & & $\mathrm{n}$ & 40 & 35 \\
\hline & Global: Mean d & erence & $0.86^{* *}$ & $0.48^{\Phi}$ \\
\hline \multicolumn{3}{|c|}{ Within No Negotiate: Mean difference } & 0.07 & $0.77^{* *}$ \\
\hline \multicolumn{3}{|c|}{ Within Negotiate: Mean difference } & $0.73^{* *}$ & 0.30 \\
\hline
\end{tabular}

${ }^{\mathrm{T}} p=.06 .{ }^{* *} p<.01$.

${ }^{\text {a }}$ Indicates a significant gender difference within condition at level of $p<.05$. 
Table 6. Study 2, Local Male Employees: Regression Analyses Illustrating Moderated Mediation Effect Following Baron and Kenney's (1986) Logical Deduction of Mediation Effects.

\begin{tabular}{|c|c|c|c|c|c|c|}
\hline \multirow[b]{2}{*}{ Predictors } & \multicolumn{2}{|c|}{$\begin{array}{c}\text { Direct Effects } \\
\text { Communal }\end{array}$} & \multicolumn{2}{|c|}{$\begin{array}{l}\text { Willingness to Work } \\
\text { with Employee }\end{array}$} & \multicolumn{2}{|c|}{$\begin{array}{c}\text { Willingness to Work } \\
\text { with Employee }\end{array}$} \\
\hline & B & $\mathrm{SE}$ & $\mathrm{B}$ & SE & B & SE \\
\hline Constant & $5.54^{* * *}$ & .19 & $5.41^{* * *}$ & .22 & $1.87^{* * *}$ & .43 \\
\hline Negotiate (Yes vs. No) & -.11 & .20 & -.21 & .22 & -.14 & .19 \\
\hline Global (vs. Local) Context & -.11 & .21 & -.07 & .24 & .01 & .20 \\
\hline Negotiate $\times$ Global & $-.68^{*}$ & .30 & $-.69^{*}$ & .34 & -.25 & .29 \\
\hline Communal & & & & & $.64^{* * *}$ & .07 \\
\hline \multicolumn{7}{|l|}{ Controls } \\
\hline Comfort in Arabic/English & .07 & .04 & $.12^{*}$ & .05 & .08 & .04 \\
\hline Private High School & -.04 & .21 & $.61^{*}$ & .24 & $.63^{* *}$ & .20 \\
\hline $\mathrm{R}^{2}$ & .11 & & .13 & & .40 & \\
\hline
\end{tabular}

${ }^{*} p<.05 .{ }^{* *} p<.01{ }^{* * *} p<.001$. 
Figure 1 Illustration of Moderated Mediation Effects Predicted in Hypothesis 6 for Male Locals (adapted from Hayes, 2013)

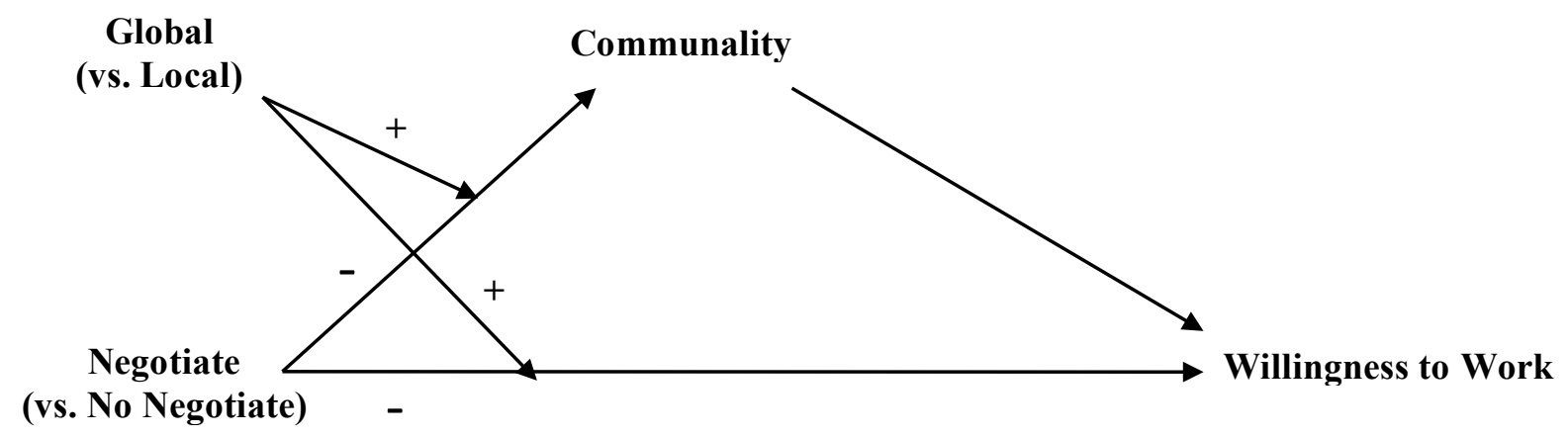


Figure 2 Exploratory Study - Pretest Survey of Local Perceptions of Stereotypic Views of Global Employers: Mean Ratings of the Perceived Competence of Local University Graduates by Local and Global Employers as Reported by College-Educated Emiratis with Work Experience ( \pm 1 SE).

${ }^{*} p<.05 .{ }^{* *} p<.01$.

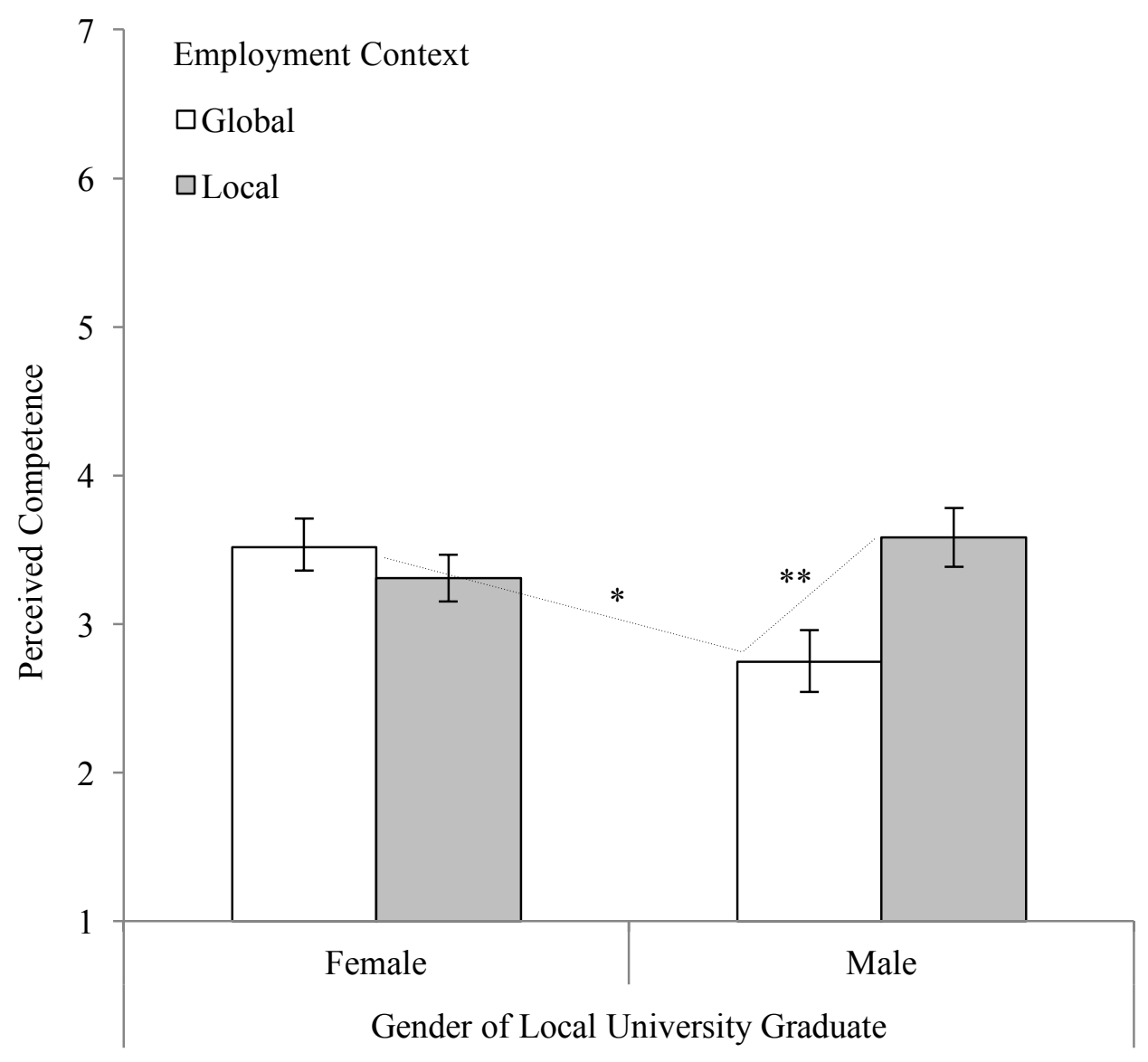


Figure 3 Study 1: Graphic Illustration of the Propensity to Self-Advocate for Higher Compensation by Employment Context and Participant Gender from the Ordered Logistic Regression Reported in Table 2, Showing the Differential Log Odds with Female Participant in Global Employment Condition as Base Case.

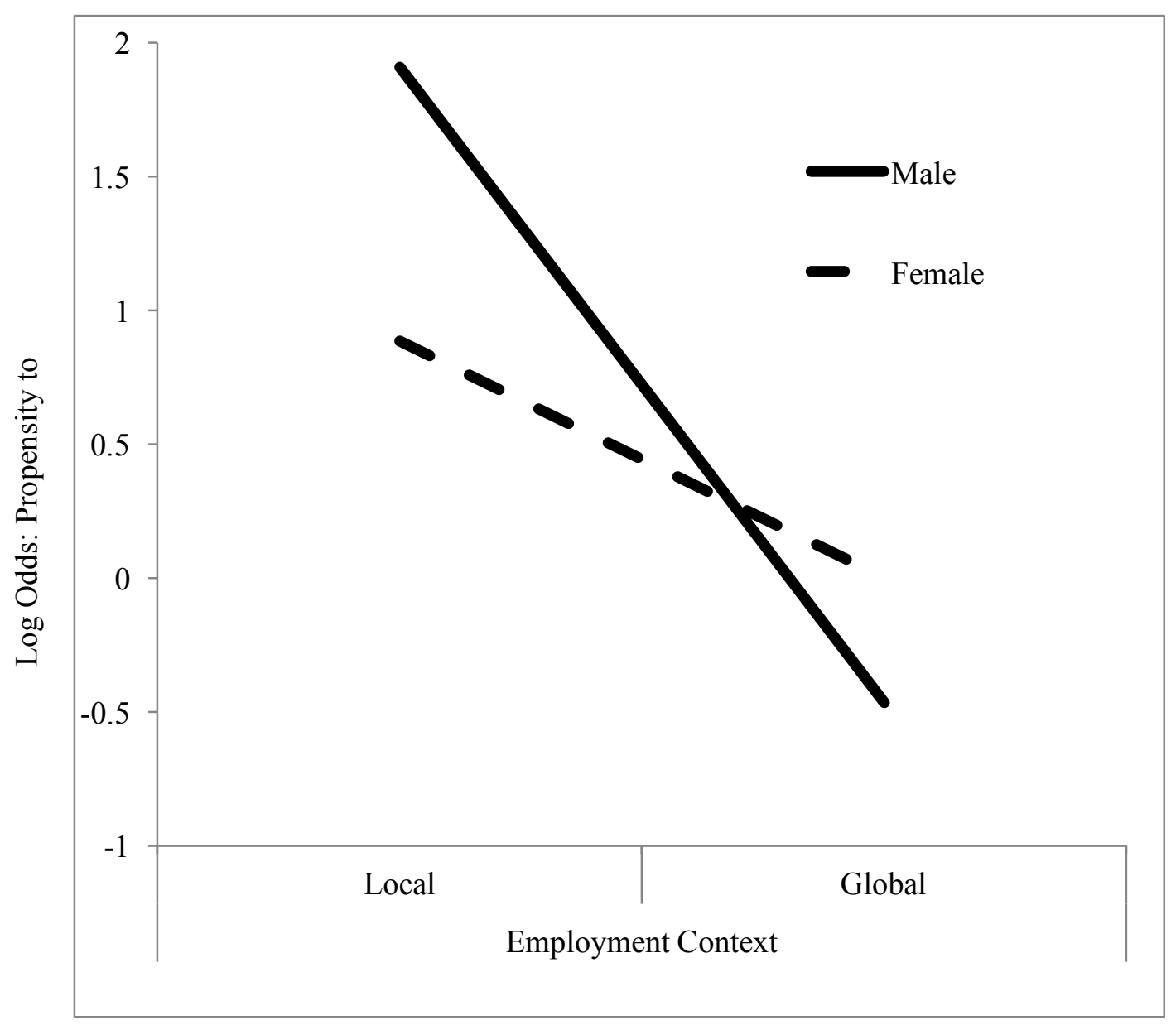


Figure 4 Study 2: Graphic Displays Estimated Marginal Mean Willingness to Work with Local Employee, Generated by ANCOVA in Table 2 Testing the Effects of Negotiating on the Willingness to Work with Male and Female Local Employees in Global and Local Employment Contexts ( \pm 1 SE).

${ }^{\mathrm{T}} p=.06 .{ }^{* *} p<.01$.

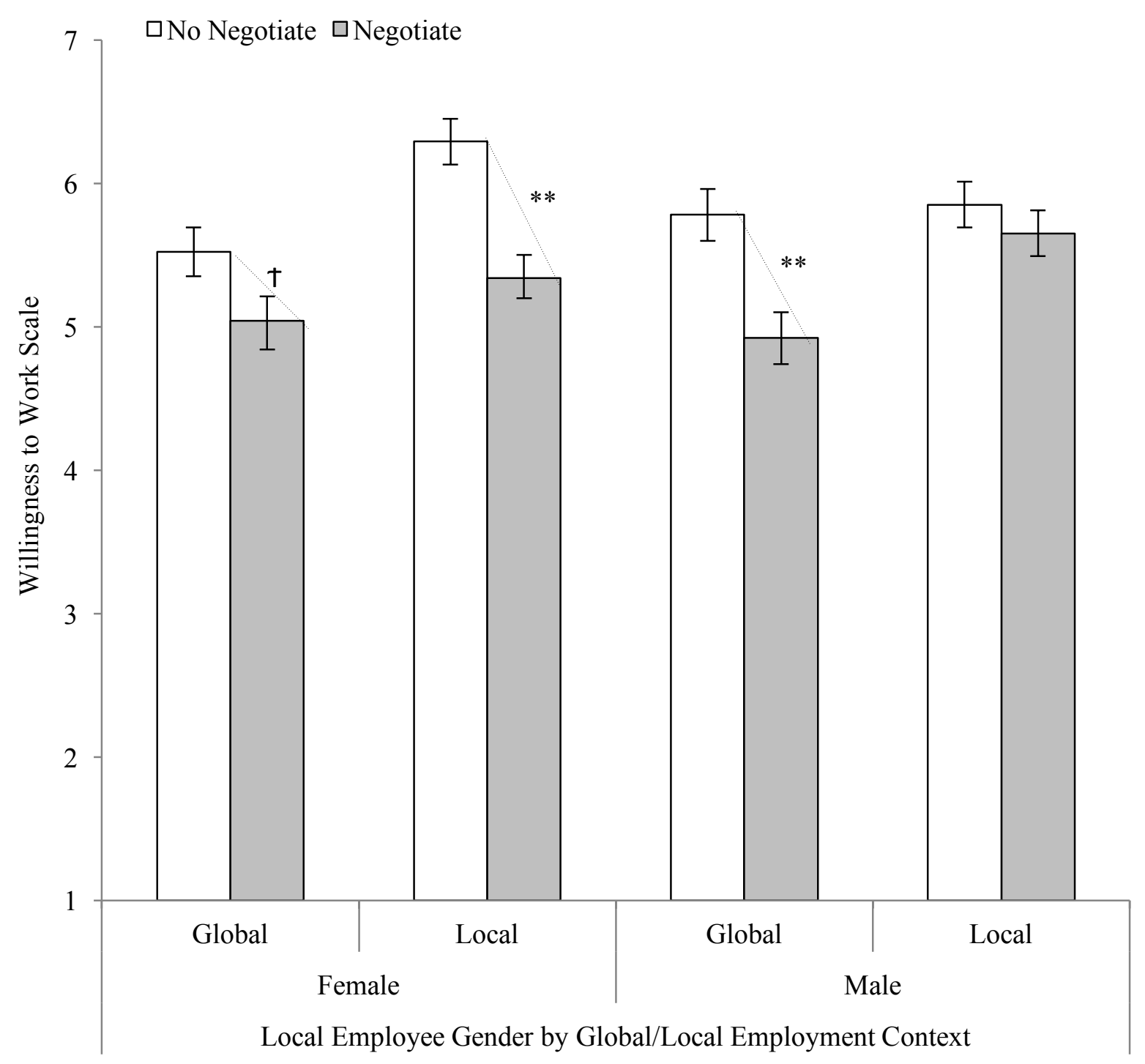


Figure 5 Model of Multiple Mediation for Local Female Employees in Study 2, Showing that Evaluators Were Less Inclined to Work with a Female Employee when She Negotiated for Higher Compensation (as Compared to When She Let the Opportunity to Negotiate Pass) Because Negotiating Made Her Appear Insufficiently Communal and Modest and Overly Materialistic (Graphic adapted from Preacher and Hayes, 2008, p. 881). All regressions included controls for participants' language proficiency. ${ }^{*} p<.05 .{ }^{* *} p<.01 .{ }^{* * *} p<.001$.

Female Employee

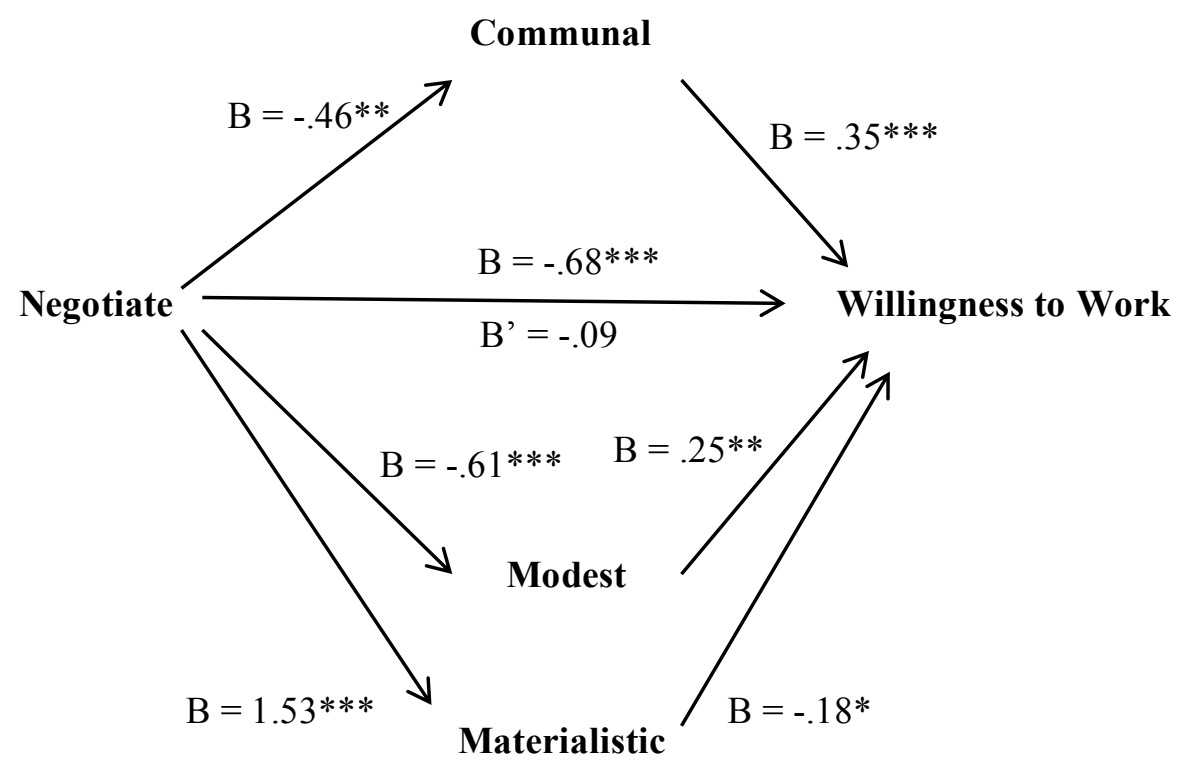

